\title{
Holocene ice-wedge polygon development in northern Yukon permafrost peatlands (Canada)
}

\author{
Michael Fritz a, b, *, Juliane Wolter a, c, Natalia Rudaya d, e, f, Olga Palagushkina ${ }^{\mathrm{g}}$, \\ Larisa Nazarova ${ }^{\text {a, c, g }}$, Jaroslav Obu ${ }^{\text {a, c }}$, Janet Rethemeyer ${ }^{\text {h }}$, Hugues Lantuit ${ }^{\mathrm{a}, \mathrm{c}}$, \\ Sebastian Wetterich ${ }^{\mathrm{a}}$ \\ ${ }^{a}$ Alfred Wegener Institute Helmholtz Centre for Polar and Marine Research, Department of Periglacial Research, Telegrafenberg A43, 14473 Potsdam, \\ Germany \\ ${ }^{\mathrm{b}}$ Utrecht University, Department of Earth Sciences, Heidelberglaan 2, 3584 CS Utrecht, The Netherlands \\ ${ }^{\mathrm{c}}$ University of Potsdam, Institute of Earth and Environmental Sciences, Karl-Liebknecht-Str. 24-25, 14476 Potsdam-Golm, Germany \\ ${ }^{\mathrm{d}}$ Institute of Archaeology \& Ethnography, Ac. Lavrentiev Ave. 17, SB RAS 630090 Novosibirsk, Russia \\ e Novosibirsk State University, Pirogova Str. 2, 630090 Novosibirsk, Russia \\ ${ }^{\mathrm{f}}$ Altai State University, Lenin Ave. 46, 656038 Barnaul, Russia \\ ${ }^{g}$ Kazan (Volga Region) Federal University, Kremlevskaya Str., 18, 420008 Kazan, Russia \\ h University of Cologne, Institute for Geology and Mineralogy, Zülpicher Str. 49a, 50674 Cologne, Germany
}

\section{A R T I C L E I N F O}

\section{Article history:}

Received 30 June 2015

Received in revised form

2 February 2016

Accepted 4 February 2016

Available online 28 February 2016

\section{Keywords:}

Permafrost peatlands

Arctic

Thermokarst

Talik

Ice-wedge polygon

Pollen

Diatoms

Plant macrofossils

Stable water isotopes

Deuterium excess

\begin{abstract}
A B S T R A C T
Ice-wedge polygon (IWP) peatlands in the Arctic and Subarctic are extremely vulnerable to climatic and environmental change. We present the results of a multidisciplinary paleoenvironmental study on IWPs in the northern Yukon, Canada. High-resolution laboratory analyses were carried out on a permafrost core and the overlying seasonally thawed (active) layer, from an IWP located in a drained lake basin on Herschel Island. In relation to 14 Accelerator Mass Spectrometry (AMS) radiocarbon dates spanning the last 5000 years, we report sedimentary data including grain size distribution and biogeochemical parameters (organic carbon, nitrogen, $\mathrm{C} / \mathrm{N}$ ratio, $\delta^{13} \mathrm{C}$ ), stable water isotopes $\left(\delta^{18} \mathrm{O}, \delta \mathrm{D}\right.$ ), as well as fossil pollen, plant macrofossil and diatom assemblages. Three sediment units (SUs) correspond to the main stages of deposition (1) in a thermokarst lake (SU1: 4950 to 3950 cal yrs BP), (2) during transition from lacustrine to palustrine conditions after lake drainage (SU2: 3950 to 3120 cal yrs BP), and (3) in palustrine conditions of the IWP field that developed after drainage (SU3: 3120 cal yrs BP to $2012 \mathrm{CE}$ ). The lacustrine phase (pre 3950 cal yrs BP) is characterized by planktonic-benthic and pioneer diatom species indicating circumneutral waters, and very few plant macrofossils. The pollen record has captured a regional signal of relatively stable vegetation composition and climate for the lacustrine stage of the record until $3950 \mathrm{cal}$ yrs BP. Palustrine conditions with benthic and acidophilic diatom species characterize the peaty shallow-water environments of the low-centered IWP. The transition from lacustrine to palustrine conditions was accompanied by acidification and rapid revegetation of the lake bottom within about 100 years. Since the palustrine phase we consider the pollen record as a local vegetation proxy dominated by the plant communities growing in the IWP. Ice-wedge cracking in water-saturated sediments started immediately after lake drainage at about $3950 \mathrm{cal}$ yrs BP and led to the formation of an IWP mire. Permafrost aggradation through downward closed-system freezing of the lake talik is indicated by the stable water isotope record. The originally submerged IWP center underwent gradual drying during the past 2000 years. This study highlights the sensitivity of permafrost landscapes to climate and environmental change throughout the Holocene.
\end{abstract}

๑) 2016 Elsevier Ltd. All rights reserved.

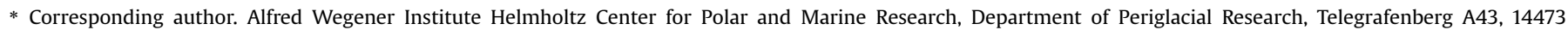
Potsdam, Germany.

E-mail addresses: michael.fritz@awi.de (M. Fritz), juliane.wolter@awi.de (J. Wolter), nrudaya@gmail.com (N. Rudaya), opalagushkina@mail.ru (O. Palagushkina), larisa.

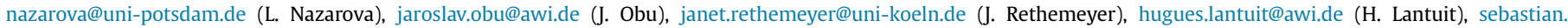
wetterich@awi.de (S. Wetterich).
} 


\section{Introduction}

IWPs are among the most typical permafrost features of Arctic lowlands. In the northern hemisphere, IWPs are thought to occupy up to 2,600,000 $\mathrm{km}^{2}$ (Mackay, 1972) of the tundra and the boreal forest zones, which is equivalent to up to $31 \%$ of the arctic land mass including glaciated regions. IWPs are characterized by peat formation and occur extensively in the coastal lowlands of eastern Siberia, Alaska and northwestern Canada. They are also common on poorly drained ground, such as river terraces and floodplains, and on the bottom of drained thermokarst lakes. These drained lakes occupy large areas of Arctic lowlands (Grosse et al., 2013), and IWPs located therein have stored large quantities of organic matter (OM) on geological timescales (Schirrmeister et al., 2011) so that they regarded as greenhouse gas sinks (Schuur et al., 2015). Hugelius et al. (2014) have estimated the soil organic carbon stock for northern peatlands to be between 302 and $338 \mathrm{Pg} \mathrm{C}$. Walter Anthony et al. (2014) emphasized the very large quantities of organic carbon (up to $159 \pm 24 \mathrm{Pg} \mathrm{C}$ ) stored in thermokarst lake basins of Holocene age in the Yedoma-region. Yedoma deposits formed during the late Pleistocene cold stages in unglaciated Beringia and are characterized by high ice contents, fine grain size, and a good preservation of organic carbon (Schirrmeister et al., 2013). As the terrestrial Arctic warms up, permafrost soils, including those located in IWPs in drained lake basins, are expected to release substantial greenhouse gas emissions that will generate a positive feedback to global warming (Dutta et al., 2006; Koven et al., 2011; Schaefer et al., 2014). Walter Anthony et al. (2014) indicated that widespread permafrost thaw could ultimately result in reduced lake and wetland abundance caused by drainage and drying, facilitating rapid decomposition of freeze-locked organic matter. Yet, these estimations were based on sampling performed on thermokarst basins in permafrost environments of the Yedoma region. They did not consider the specifics of drained lake environments in epigenetic permafrost environments outside the Yedoma region, which are by far more abundant and where epigenetic ice-wedge growth produces different IWP morphologies (French, 2007). In this paper, we study IWP peatland development after lake drainage in a thermokarst basin that formed in ice-rich epigenetic permafrost. Moreover, the presence of IWPs in Arctic drained thermokarst lake basins is well-known but the mechanisms involved in their formation remain largely unclear apart from IWP formation resulting from experimental drainage (Mackay, 1981, 1986, 1988; Mackay and Burn, 2002). Climate has been proposed to be driver of thermokarst lake development and drainage (e.g. Vardy et al., 1997, 1998), but the role of local settings in surface morphology and hydrology is also stressed by a few studies (Vardy et al., 2005; Ellis and Rochefort, 2006; Zibulski et al., 2013). External climate forcing and internal processes such as permafrost phenomena, small-scale changes in morphology, hydrology, and vegetation succession interact with each other, including a complex chain of feedback mechanisms (Wolter et al., accepted). The role and impact of climate and vegetation feedbacks to permafrost is especially important in this context.

Based on a 233-cm-long permafrost section including the seasonally frozen active layer from an IWP mire, we investigate the relationship between thermokarst, IWP formation and vegetation on a decadal to centennial resolution in order to understand the interplay of thermokarst lake and IWP mire dynamics. This multidisciplinary study aims at:

(1) reconstructing IWP development and peat accumulation in areas of continuous permafrost,

(2) evaluating the influence of internal and external environmental drivers of IWP mires, and
(3) reviewing Holocene IWP formation and development in response to permafrost formation, thermokarst, lake drainage and vegetation succession.

\section{Background}

\subsection{Thermokarst and thaw lake dynamics}

Permafrost degradation (thermokarst) leads to the formation of thaw lakes which expand in size due to shore erosion and in depth due to surface subsidence together with ground-ice melting. Thermokarst lakes in arctic tundra landscapes are very dynamic features with a highly variable timing in terms of life cycle (e.g. Lenz et al., 2015). This cycle includes initiation, expansion, drainage and eventual re-initiation (Van Huissteden et al., 2011). Their lifetime in contrast to the onset - largely depends on local factors such as geomorphology, ground-ice conditions, hydrology and groundsurface stability (Jones et al., 2011, 2012; Jones and Arp, 2015). The initiation of many thermokarst lakes in northwest Canada, Alaska, and Siberia is related to increasing air temperatures, available moisture and permafrost thaw in response to short-term warming events during the Pleistocene-Holocene transition or later on during the Holocene thermal maximum (Rampton, 1988; Brosius et al., 2012; Walter Anthony et al., 2014). However, Burn and Smith (1990) noted that such lakes may also develop in response to site-specific factors such as ground disturbance, which are not necessarily related to regional climatic change.

\subsection{Ice-wedge-polygon (IWP) development}

Strongly decreasing air temperatures in winter lead to thermal contraction of the exposed ground so that frost cracks occur (Lachenbruch, 1962). Snow, hoar frost and spring meltwater fill in the cracks to form vertical ice veins that may grow into ice wedges after numerous freeze-thaw cycles. Physical self-organization leads to the surface expression of polygonal patterns on the ground surface with ice wedges below the rims and sedimentary centers together forming ice-wedge polygons (Krantz, 1990). Lateral and vertical material displacement during frost cracking and infilling of cracks with ice in primary IWPs form elevated rims above the ice wedges and low water-logged centers, i.e. low-centered IWPs with intrapolygonal ponds (Fig. 1a). High-centered IWPs (Fig. 1c) develop due to topographic inversion when ice wedges melt and IWP rims degrade or when peat growth and sediment accumulation rates in the centers exceed syngenetic growth rates of ice wedges (French, 2007). IWPs are not only characterized by this modern typology, but also by different generations of ice wedges and corresponding sedimentary records under the IWP centers. Surficial expression is mostly associated with recent or actively cracking IWPs. Inactive IWP and associated ice wedges that have been degraded in depth are often buried under a sediment cover with a thickness that roughly corresponds to the paleoactive-layer depth, added by the sediment thickness deposited since thaw and subtracted by the excess ice volume (cf. Burn et al., 1986; Burn, 1997; see section 6.2.2). Therefore, remote sensing methods fail to reliably register IWPs that are missing a surface expression. A substantial underestimation of the surface area covered by IWPs in the Arctic ultimately misjudges the extent and impacts of future thaw and degradation.

The combination of high contents of intrasedimental ice in IWP centers and massive ice wedges below troughs/rims with smallscale topographic variations on the surface leads to very heterogeneous conditions, which make IWP systems extremely sensitive to environmental change. Furthermore, IWP ponds and 


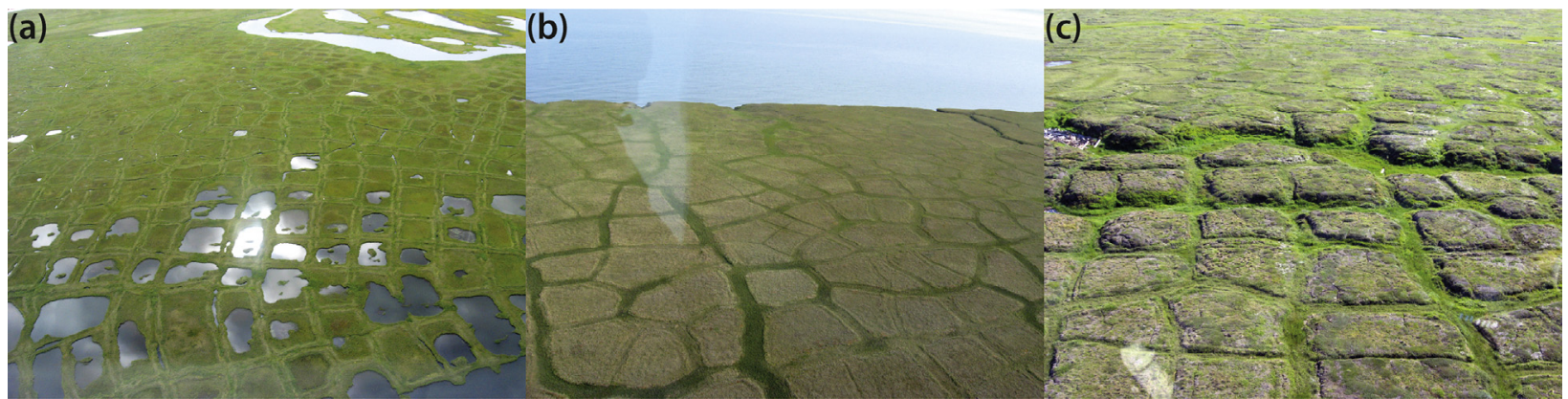

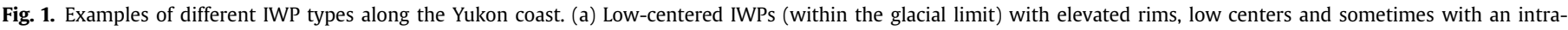

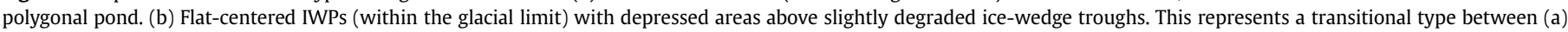
and (c). (c) High-centered IWPs (beyond the glacial limit) with elevated centers and strongly degraded troughs due to ice-wedge melting.

thermokarst lakes are abundant aquatic ecosystem types in the Arctic (Grosse et al., 2013). They are hotspots of biological activity and diversity (Smol and Douglas, 2007), providing diverse habitats for microorganisms, plants, birds, and aquatic communities (Palagushkina et al., 2012; Bobrov et al., 2013; De Klerk et al., 2014). Continuous organic matter accumulation and preservation during syngenetic permafrost aggradation make northern IWPs a valuable climate and environmental archive. A number of paleoenvironmental reconstructions from NE Siberian permafrost employ late Pleistocene and Holocene IWP deposits (e.g. Andreev et al., 2011; De Klerk et al., 2011; Wetterich et al., 2014) to reconstruct longterm environmental history and to develop an understanding of IWP formation and degradation. North American studies on IWPs focus mainly on postglacial deposits, because of the regional Quaternary history (Ovenden, 1982; Vardy et al., 1997, 1998, 2005; Eisner and Peterson, 1998a,b; Eisner et al., 2005). These investigations apply palynology, plant macrofossils, loss on ignition, and sometimes stable water isotopes to reconstruct climate-related patterns of hydrology and vegetation change as well as to assess the influence of permafrost on carbon storage in polygonal peatlands.

\section{Study area}

The Northern Yukon is characterized by continuous permafrost (Brown et al., 1998) and tundra vegetation in a subarctic climate. North of the British Mountains the Yukon Coastal Plain stretches $200 \mathrm{~km}$ from the Alaskan border to the Mackenzie Delta. It is confined to the north by the Beaufort Sea where Herschel Island is the only prominent island apart from barrier islands along the mainland coast (Fig. 2). Unconsolidated sediments and high ground ice volumes make the region vulnerable to ground subsidence and erosion under permafrost thaw conditions (Rowland et al., 2010; Fritz et al., 2012a). Herschel Island is a glacial push-moraine originating from an advance of the Laurentide Ice Sheet into the Northern Yukon during the Late Wisconsin (23-15 kyr BP) (Mackay, 1959; Dyke and Prest, 1987; Fritz et al., 2012a). It is made up of redeposited marine and terrestrial sediments mixed into a glacial diamicton (Bouchard, 1974; Rampton, 1982). The island measures 15 by $8 \mathrm{~km}$ across and rises to ca. $180 \mathrm{~m}$ above sea level. Ground ice volumes exceeding 50\% (Couture, 2010), high coastal bluffs, and a generally high relief energy promote coastal erosion, intensive gullying through thermal erosion and locally variable ground subsidence through thawing permafrost. These processes provide Herschel Island with a high spatial and temporal variability in surface relief and disturbance regime (Obu et al., 2015, Fig. 3a). Ice wedges underlie most of the island's surface and include syngenetic, anti-syngenetic and epigenetic formations. The setting of the studied IWP mire on Herschel Island is comparable to that of low-centered IWP fields on the Yukon mainland and in the Alaskan or Siberian Arctic lowlands (see above). Mean annual air temperatures are $-11{ }^{\circ} \mathrm{C}$ ca. $50 \mathrm{~km}$ west of Herschel Island at Komakuk Beach and $-9.9^{\circ} \mathrm{C}$ ca. $100 \mathrm{~km}$ east of Herschel Island at Shingle Point for the period 1971-2000 (Environment Canada; http:// climate.weather.gc.ca). Mean annual precipitation for the same period amounts to $161 \mathrm{~mm}$ at Komakuk Beach and $254 \mathrm{~mm}$ at Shingle Point. Mean ground temperature (August 2014-August 2015 ) in the studied polygon at $90 \mathrm{~cm}$ depth was $-4.6{ }^{\circ} \mathrm{C}$ in the center and $-5.4{ }^{\circ} \mathrm{C}$ under the polygon rim (unpublished data). Burn and Zhang (2009) studied permafrost conditions at Collinson Head on Herschel Island and measured mean annual ground temperatures at $1 \mathrm{~m}$ depth in the range from $-4.0^{\circ} \mathrm{C}$ beneath a snow bank to between -9.0 and $-6.2{ }^{\circ} \mathrm{C}$ at other sites. The depth of zero annual amplitude was estimated to $14.5 \mathrm{~m}$ with a mean annual ground temperature of $-8.0{ }^{\circ} \mathrm{C}$ (Burn and Zhang, 2009). The vegetation on Herschel Island is classified as erect dwarf shrub tundra in the Circumpolar Arctic Vegetation Map (Walker et al., 2005), although more recent studies have shown an increase in low shrubs on the island (Myers-Smith et al., 2011). Wetland vegetation in the region consists of mosses, sedges and erect dwarf shrubs less than $40 \mathrm{~cm}$ tall (Walker et al., 2005).

\section{Material and methods}

\subsection{Field work}

At the coring location, a detailed terrain and vegetation survey was undertaken to characterize the surface. The studied IWP $\left(69.57953^{\circ} \mathrm{N}, 138.95740^{\circ} \mathrm{W}\right)$ is part of an IWP field situated in a shallow basin between rolling hills (Fig. 3a, b). The IWP field has a drainage outlet towards the coast, where coastal bluffs are about $25 \mathrm{~m}$ high (Fig. 3a, b). The troughs surrounding the IWP are watersaturated, often with visible ponds (Fig. 3c). The polygon measures $16 \mathrm{~m}$ from rim to rim and the maximum elevation difference between low-lying center and elevated rim is $25 \mathrm{~cm}$. The vegetation in the IWP consists of graminoids, dwarf shrubs and mosses. Forbs occur in low abundance. There is a clear difference in vegetation composition between elevated rims and low-lying centers (Wolter et al., accepted). The IWP center is dominated by sedges (Carex aquatilis, C. chordorrhiza, C. rariflora, C. williamsii) and Alaska bog willow (Salix fuscescens). Pedicularis sudetica, Polygonum viviparum, and Luzula wahlenbergii occur in low abundance. On the IWP rims, various dwarf shrubs (Betula glandulosa, Salix pulchra, S. reticulata, Rubus chamaemorus, Cassiope tetragona, Ledum decumbens, Vaccinium uliginosum, V. vitis-idaea), tussock cottongrass (Eriophorum vaginatum) and other herbs (Carex rariflora, Pyrola grandiflora, Poa arctica, Hierochloë alpina) are found. Common cottongrass 


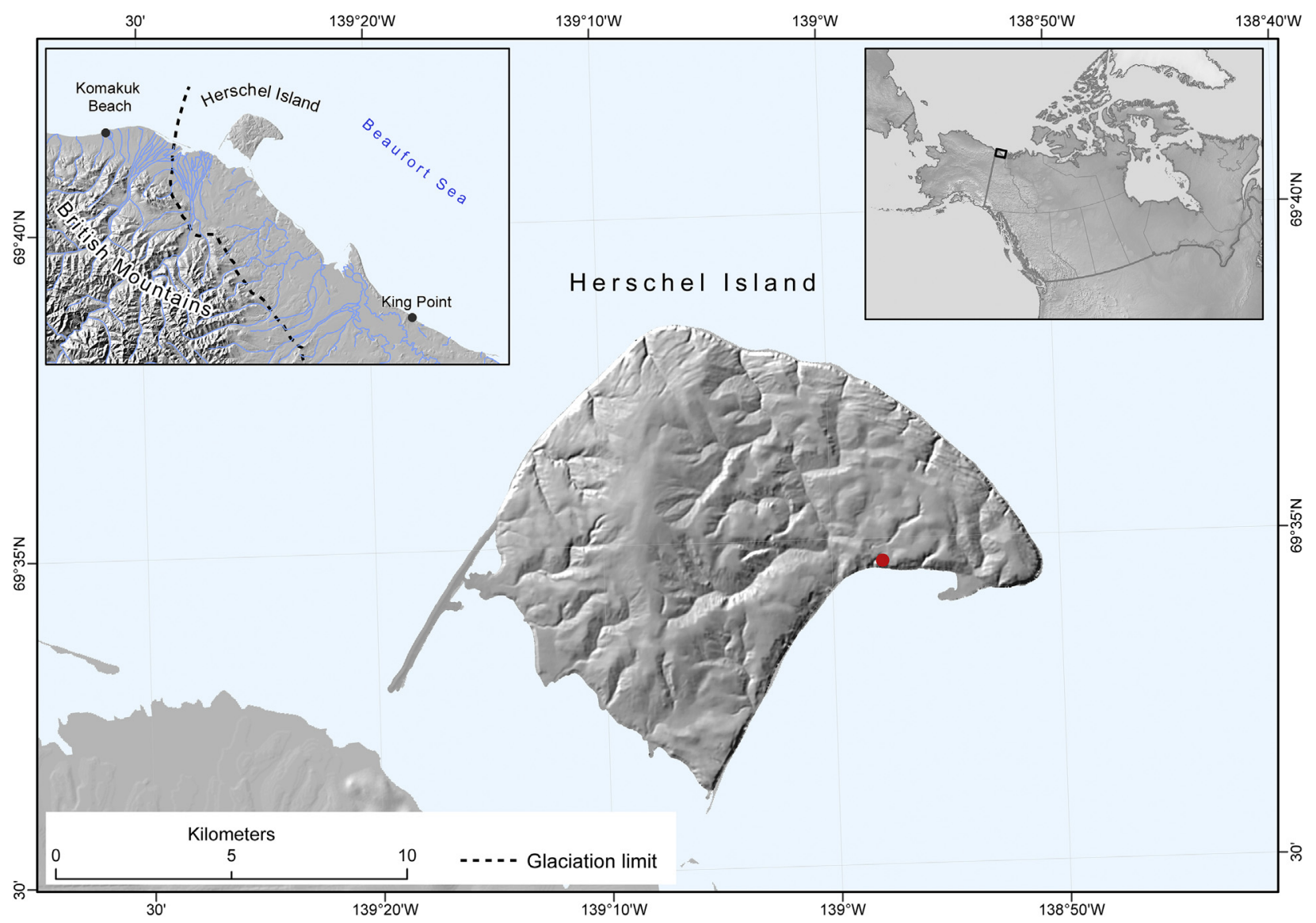

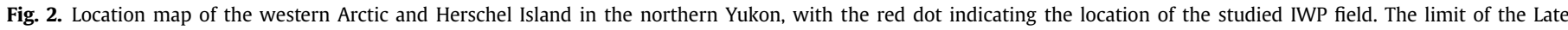
Wisconsin Laurentide Ice Sheet follows that of Dyke and Prest (1987). The base layer was provided by Yukon Geomatics.

(Eriophorum angustifolium) dominates in ice-wedge troughs and is accompanied by water sedge (Carex aquatilis), marsh cinquefoil (Potentilla palustris), and mare's tail (Hippuris vulgaris). Mosses are ubiquitous, but have not been surveyed in detail.

The core material was accessed by digging a pit until the permafrost table was reached. The $32-\mathrm{cm}$ thick active-layer monolith (code: YC12-HP-Mc) was recovered and subsampled in one-centimeter increments ( 32 samples). Coring was carried out on 3 August 2012 with a SIPRE permafrost drill equipped with a Stihl BT 121 engine and auger barrel with a diameter of $7.5 \mathrm{~cm}$. The permafrost core of $201 \mathrm{~cm}$ (code: PG2100) was sampled continuously in $2-3 \mathrm{~cm}$ increments (77 samples).

\subsection{Radiocarbon dating and geochronology}

Hand-picked terrestrial plant remains $>250 \mu \mathrm{m}$ from 14 samples at selected depth levels were dated using Accelerator Mass Spectrometry (AMS) ${ }^{14} \mathrm{C}$ radiocarbon dating (Table 1). All plant fragments were first cleaned with water. Very small and fragile samples were pre-treated with $1 \% \mathrm{HCl}(\mathrm{A}$ ) only (ca. $10 \mathrm{~h}$, room temperature) to remove possible inorganic carbon. Larger plant fragments were treated by standard acid-alkali-acid extraction (AAA) to remove both inorganic carbon and humic substances by sequential extraction with $1 \% \mathrm{HCl}, 1 \% \mathrm{NaOH}\left(4 \mathrm{~h}, 60^{\circ} \mathrm{C}\right)$, and again $1 \% \mathrm{HCl}$ (ca. $10 \mathrm{~h}$, room temperature). After each extraction step the plant fragments were washed repeatedly with Milli-Q water. The dried $\left(60^{\circ} \mathrm{C}\right)$ samples were then graphitized with an automatic graphitization system (Wacker et al., 2010; Rethemeyer et al., 2013) and ${ }^{14} \mathrm{C}$ concentrations were analyzed at CologneAMS, Germany (COL), and Poznan Radiocarbon Laboratory, Poland (Poz). The conventional ${ }^{14} \mathrm{C}$ ages are reported in years before present (yrs BP) with one-sigma measurement uncertainty. The obtained conventional ${ }^{14} \mathrm{C}$ ages were calibrated using the IntCal13 calibration curve (Reimer et al., 2013). The age depth relation was constructed with Bacon 2.2 modelling routines in R (Blaauw and Christen, 2011). The weighted average of the probability distribution was used to fix a specific age for each centimeter along the core. In the model we used default settings, but changed accumulation mean to $15 \mathrm{~cm}$, memory strength to 15 and memory mean to 0.45 . Calibrated radiocarbon ages are given as cal yrs $B P$.

\subsection{Sedimentology}

The gravimetric water content in frozen sediments, expressed as weight percent (wt.\%), was determined as the mass ratio of ice to dry sample according to Van Everdingen (1998). A laser particle analyzer (Coulter LS 200) was used for grain-size analyses on freeze-dried and organic-free (treated with $30 \% \mathrm{H}_{2} \mathrm{O}_{2}$ ) subsamples. Total organic carbon (TOC) and total nitrogen (TN) contents were measured with Elementar Vario MAX C and Elementar Vario EL III element analyzer, respectively, and are given as weight percent (wt.\%). The $\mathrm{C} / \mathrm{N}$ ratio is expressed by the quotient of TOC and TN values. Stable carbon isotope ratios $\left(\delta^{13} \mathrm{C}\right)$ of TOC were measured on carbonate-free samples with a Finnigan DELTA-S mass spectrometer. The values are expressed in delta per mil notation $(\delta \%$ ) relative to the Vienna Pee Dee Belemnite (VPDB) standard.

Sediment units were defined using the parameters TOC, $\mathrm{C} / \mathrm{N}$ and $\delta^{13} \mathrm{C}$ in a stratigraphically constrained cluster analysis and a broken 

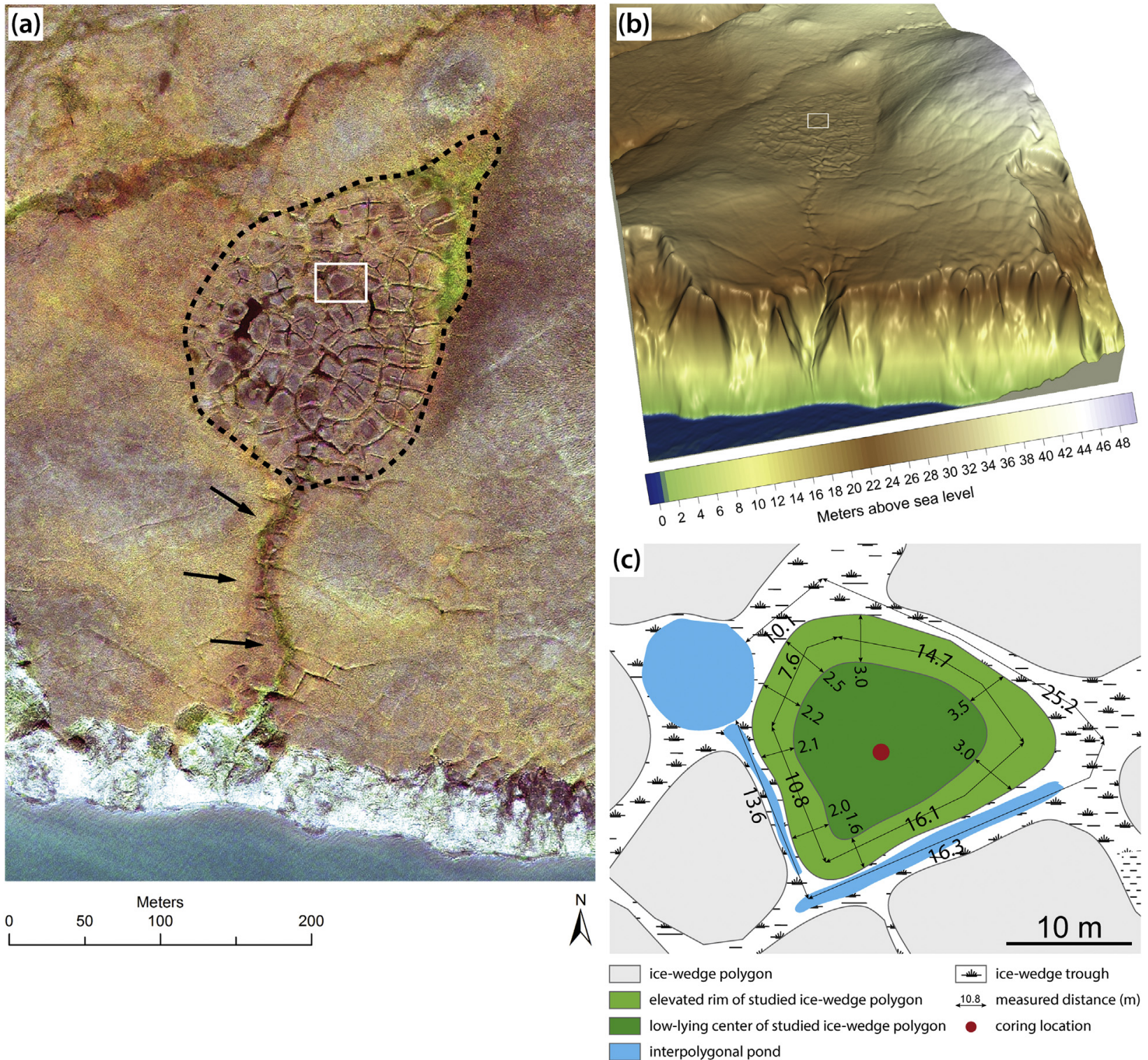

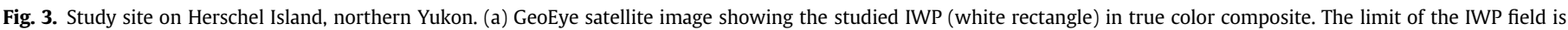

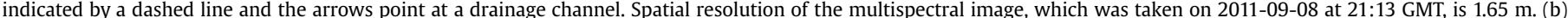

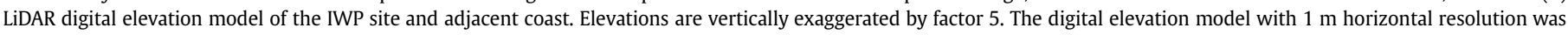

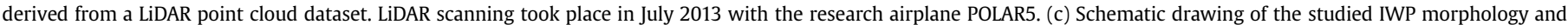
dimensions. Photographs of the studied polygon, the active-layer pit and the unfrozen peat monolith can be found in Supplementary Fig. S1.

stick model. For these analyses the data was normalized using range transformation (function tran in R package 'analogue') to bring the parameters onto the same scale. We calculated a Euclidean dissimilarity matrix (function vegdist in $\mathrm{R}$ package 'vegan') to quantify the dissimilarity between samples in a simple way minimizing pre-assumptions about the data structure. This quantification was needed to calculate the Constrained Incremental Sum of Squares (CONISS) algorithm (Grimm, 1987) and a broken stick model (functions chclust and bstick in R package 'rioja') to find the maximum feasible number of sediment units (Bennett, 1996).

\subsection{Stable water isotopes of pore water and intrasedimental ice}

Pore water and supernatant water from thawed sediments was extracted using rhizon soil moisture samplers $($ SMS $5 \mathrm{~cm}$,
Eijkelkamp). The hydrogen and oxygen isotope composition ( $\delta \mathrm{D}$, $\delta^{18} \mathrm{O}$ ) was determined with a Finnigan MAT Delta-S mass spectrometer, using the equilibration technique (Horita et al., 1989). Values are given as per mil difference from Vienna Standard Mean Ocean Water (VSMOW), with internal $1 \sigma$ errors of better than 0.8 and $0.1 \%$ for $\delta \mathrm{D}$ and $\delta^{18} \mathrm{O}$, respectively (Meyer et al., 2000). The results are presented in $\delta \mathrm{D}-\delta^{18} \mathrm{O}$ diagrams with respect to the Global Meteoric Water Line (GMWL; $\delta \mathrm{D}=8 \delta^{18} \mathrm{O}+10$; Craig, 1961) and to the modern Local Meteoric Water Line (LMWL) derived from long-term observations in Inuvik $\left(\delta \mathrm{D}=7.3 \delta^{18} \mathrm{O}-3.5 ; \mathrm{R}^{2}=0.98\right.$; IAEA, 2015). Second-order parameters, such as the linear $\delta \mathrm{D}-\delta^{18} \mathrm{O}$ regression slope and the deuterium excess $\left(d\right.$-excess $=\delta \mathrm{D}-8 \delta^{18} \mathrm{O}$; Dansgaard, 1964), were calculated and provide insight into the water source of the initial precipitation and the presence or absence of secondary non-equilibrium fractionation processes. 
Table 1

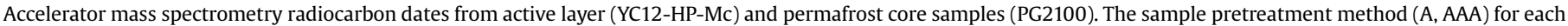
sample is keyed in the text.

\begin{tabular}{|c|c|c|c|c|c|c|c|}
\hline Lab No. & $\begin{array}{l}\text { Depth level } \\
\text { [cm below surface] }\end{array}$ & $\begin{array}{l}\text { Age } \\
{\left[{ }^{14} \mathrm{C} \text { yrs BP] }\right.}\end{array}$ & $\begin{array}{l}\text { Calibrated age ranges } \\
\text { [cal yrs BP] } 1 \sigma \\
\text { confidence interval }\end{array}$ & $\begin{array}{l}\text { Dated material } \\
\text { (Terrestrial plant remains) }\end{array}$ & $C[\mu \mathrm{g}]$ & $\begin{array}{l}\delta^{13} \mathrm{C} \\
{[\% \text { vs.VPDB] }}\end{array}$ & $\begin{array}{l}\text { Sample } \\
\text { pre-treatment }\end{array}$ \\
\hline \multicolumn{8}{|c|}{ Active-layer samples (YC12-HP-Mc) } \\
\hline COL2940.1.1 & $7-8$ & $232 \pm 32$ & $0-306$ & Cyperaceae & 988 & -25.5 & AAA \\
\hline COL2941.1.1 & $15-16$ & $1259 \pm 32$ & $1179-1261$ & Cyperaceae & 988 & -26.4 & AAA \\
\hline COL2942.1.1 & $23-24$ & $1777 \pm 32$ & $1621-1731$ & Carex sp., Eriophorum sp., Ericaceae & 994 & -23.4 & AAA \\
\hline Poz-56552 & $30-31$ & $1980 \pm 40$ & 1889-1986 & Carex sp., Ledum decumbens, other Ericaceae & 600 & -41.3 & AAA \\
\hline \multicolumn{8}{|c|}{ Permafrost core samples (PG2100) } \\
\hline COL2639.1.1 & $34-36$ & $2192 \pm 37$ & $2148-2306$ & Carex sp., Ledum decumbens, other Cyperaceae & 1000 & -27.1 & A \\
\hline COL2640.1.1 & $40-42$ & $2280 \pm 37$ & $2185-2348$ & Carex sp. & 820 & -27.1 & A \\
\hline COL2641.1.1 & $66-68$ & $2988 \pm 35$ & $3078-3215$ & wood, Eriophorum sp., unidentified plant remains & 1000 & -27.6 & AAA \\
\hline COL2642.1.1 & $95-98$ & $3139 \pm 36$ & $3269-3438$ & Carex sp., moss, unidentified plant remains & 988 & -26.4 & A \\
\hline COL2643.1.1 & $128-130$ & $3467 \pm 37$ & $3649-3826$ & Carex sp., wood, unidentified plant remains & 895 & -27.8 & A \\
\hline COL2644.1.1 & $145-148$ & $3622 \pm 37$ & $3885-3980$ & $\begin{array}{l}\text { Carex sp., Potentilla palustris, wood, unidentified } \\
\text { plant remains }\end{array}$ & 930 & -26.6 & A \\
\hline COL2645.1.1 & $154-157$ & $3511 \pm 36$ & $3721-3838$ & $\begin{array}{l}\text { Carex sp., Eriophorum sp., Potentilla palustris, } \\
\text { Ledum decumbens }\end{array}$ & 988 & -24.5 & A \\
\hline COL2646.1.1 & $176-179$ & $3388 \pm 37$ & $3586-3687$ & Carex sp., Potentilla palustris, moss & 994 & -25.1 & A \\
\hline COL2647.1.1 & $214-216$ & $3678 \pm 38$ & $3933-4084$ & $\begin{array}{l}\text { Potentilla palustris, Rubus chamaemorus, } \\
\text { unidentified plant remains }\end{array}$ & 1000 & -26.9 & A \\
\hline COL2648.1.1 & $228-231$ & $4363 \pm 43$ & $4865-4968$ & Cyperaceae, moss, unidentified plant remains & 552 & -29.1 & A \\
\hline
\end{tabular}

\subsection{Palynology and plant macrofossils}

A total of 35 samples, each consisting of 0.3 up to $1.1 \mathrm{~g}$ of dry sediment, were taken every $5-10 \mathrm{~cm}$ and treated for pollen analysis using the standard procedure that includes treatment with $\mathrm{HCl}$ and $\mathrm{KOH}$, sieving $(250 \mu \mathrm{m})$, treatment with $\mathrm{HF}$, acetolysis, and mounting in glycerin (cf. Fægri and Iversen, 1989). One Lycopodium spore tablet was added to each sample in order to calculate total pollen and spore concentrations (cf. Stockmarr, 1971). Pollen and spore residues were analyzed under a light microscope Zeiss AxioImager D2 at $400 \times$ magnification. Identification of pollen and spores was performed using pollen atlases (e.g. Beug, 2004). Nonpollen palynomorphs (NPPs) were identified using descriptions and photographs published by Van Geel (2001). In total, 56 palynomorph types including 43 pollen and spore taxa were identified. A minimum of 300 terrestrial pollen grains per sample was counted. Pollen and spores that appeared to be redeposited were excluded from percentages of pollen and spores and from cluster analysis for zonation. The results of pollen analysis are displayed in a simplified pollen diagram produced with Tilia software (Grimm, 2004); the definition of the pollen zones (PZs) is supported by the CONISS algorithm. The complete counting protocol is available in the supplementary online material (SOM) to this article. Mean July air temperatures ( $\mathrm{T}_{\text {July }}$ ) were reconstructed using the modern analogue technique (MAT) and a calibration data set (training sets) from North America and Greenland (Whitmore et al., 2005). Only sites located north of $55^{\circ} \mathrm{N}$ (excluding Greenland) were included into the model. The resulting $\mathrm{T}_{\text {July }}$ training set contained 1070 sites, 134 pollen taxa and a temperature gradient from 0.7 to $17.8^{\circ} \mathrm{C}$. The MAT model had a coefficient of determination $\mathrm{r}^{2}=0.83$ and a root mean square error of prediction (RMSEP) of 1.38. Reconstruction was performed using C2 version 1.5 (Juggins, 2007).

Macrofossils of vascular plants were picked from $50 \mathrm{ml}$ sample volumes. The material was washed through a $250 \mu \mathrm{m}$ sieve and picked under a stereo-microscope. Seeds and leaves were identified by comparison with reference material and by using seed identification manuals (e.g. Berggren, 1969, 1981; Anderberg, 1994). The presence or absence of Sphagnum leaves, Daphnia resting eggs and Trichoptera cases was recorded and the composition of unidentifiable plant material was characterized by giving percentages for moss, Cyperaceae and wood.

\subsection{Diatom analysis}

A total of 20 samples were processed for diatom analysis, following the standard technique for diatom extraction in a water bath described by Battarbee (1986), using 30\% $\mathrm{H}_{2} \mathrm{O}_{2}, 10 \% \mathrm{HCl}, 1 \%$ $\mathrm{NH}_{4}^{\dagger}$ for removal of carbonates and organics, and Naphrax diatom mounting medium for slide preparation. Slides were examined at $1000 \times$ magnification using a Zeiss Axioplan microscope equipped with an oil-immersion objective. Up to 300 valves per sample were counted and identified. Taxa with abundances of $\geq 10 \%$ per sample were defined as dominants, and taxa with abundances of $\geq 5 \%$ were defined as subdominants (see section 5.5). The complete counting protocol is available in the SOM to this article. The identification of diatoms was made at the lowest possible taxonomic level following Krammer and Lange-Bertalot (1986, 1988, 1991). Biogeographical and ecological characteristics of the taxa, with respect to preference of habitat, water salinity and $\mathrm{pH}$, were described following Barinova et al. (2006). The trophic level of the lake was classified according to Reynolds (2003). Principal component analysis (PCA) was performed using CANOCO 4.5 (Ter Braak and Šmilauer, 2002) to provide insights into the underlying data structure. The reconstructions of $\mathrm{pH}$ and total phosphorus (TP) were based on the European Diatom Database facility (Battarbee et al., 2001) using combined TP and pH datasets. Stratigraphic diagrams were produced using C2 version 1.5 (Juggins, 2007). The diatom diagram was subdivided into two zones based on stratigraphical cluster analysis performed in the software PAST (Hammer et al., 2001).

\section{Results}

\subsection{Geochronology}

The fourteen radiocarbon dates indicate a mid to late Holocene age for the record, which spans the time between about 4950 cal yrs BP and 2012 CE, when the material was recovered (Table 1, Fig. 4). Sediment accumulation in the upper $70 \mathrm{~cm}$ was very slow $\left(0.03 \mathrm{~cm}_{\text {year }}{ }^{-1}\right)$. Slight age inversions (Table 1 ) were not excluded from the age-depth model as they were not recognized as outliers by the model. High accumulation rates between 4000 and 3500 cal yrs BP led to overlapping age ranges and dated material occasionally consisted of unidentified plant macro-remains which 
could have contained slightly older material. The general trend in the age-depth relationship, however, is maintained so that continuous deposition is assumed. Sample depths were transformed into depositional ages with decadal resolution in subsequent analysis and interpretation of the proxy data.

\subsection{Sedimentology}

Three major sediment units (SU) were defined with regard to sedimentary and biogeochemical properties of the permafrost core and the active layer (Fig. 5). The presented division of the record is based on the parameters TOC, $\mathrm{C} / \mathrm{N}$ and $\delta^{13} \mathrm{C}$, which serve as proxies for organic matter accumulation, preservation and its origin.

SU1 (4950-3950 cal yrs BP) is characterized by variable water contents between 61 and $88 \%$ (mean: $74 \% \pm 6.9$ ). TOC values range between 4.1 and $12.2 \%$ (mean: $5.7 \% \pm 1.9$ ) with a low standard deviation, which depicts the general homogeneity of SU1. C/Nratios vary between 11 and 16 (mean: $12 \pm 1.3$ ), and $\delta^{13} \mathrm{C}$ values vary very little between -28.0 and $-27.3 \%$ (mean: $-27.5 \%$ ). The grain size composition is rather variable; generally silt-dominated, with values between 19 and $68 \%$ (mean: $49 \% \pm 13.4$ ), but also holds considerable amounts of clay (mean: $21 \% \pm 9.1$ ) and sand (mean: $29 \% \pm 22.2$ ).

In SU2 (3950-3120 cal yrs BP), the water content varies between 71 and $85 \%$ with a mean value of $79 \%( \pm 11.1)$, which is somewhat higher than in unit SU1. TOC also reaches much higher values between 7.1 and $22.6 \%$ (mean: $14.7 \% \pm 5.1$ ) and suddenly rises from values below $10 \%$ towards values well above $15 \%$. C/Nratios range from 12 to 20 (mean: $16 \pm 2.7$ ), and $\delta^{13} \mathrm{C}$ values are between -28.7 and $-27.5 \%$ (mean: $-28.1 \%$ ), showing a wider

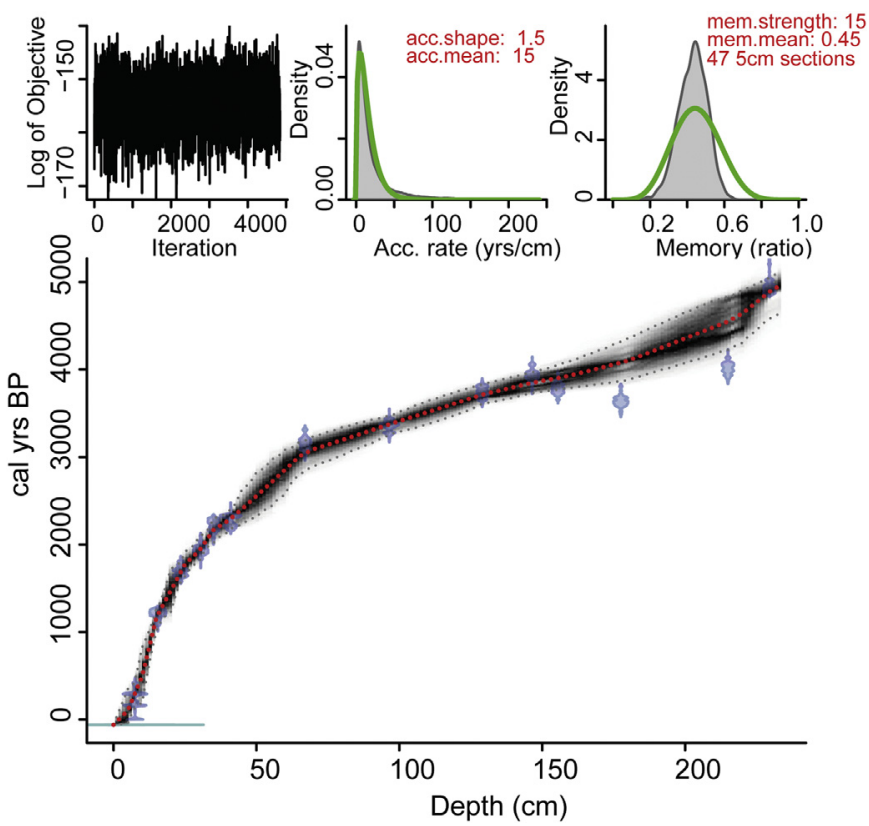

Fig. 4. Age-depth model for the active-layer peat section YC12-HP-Mc and the permafrost core PG2100 on Herschel Island, northern Yukon. The age-depth model was calculated using Bacon 2.2 modelling routines (Blaauw and Christen, 2011) from 14 AMS ${ }^{14} \mathrm{C}$ dates and calibrated with the IntCal13 calibration curve (Reimer et al., 2013). The red dotted line indicates median ages modelled for each centimeter along the core. Calibrated AMS ${ }^{14} \mathrm{C}$ dates are shown as transparent blue violin plots. Grey stippled lines illustrate $95 \%$ confidence intervals of the modelled age-depth relationship. The three upper graphs describe the quality of Markov Chain Monte Carlo iterations the model produced. The left graph shows the variance between iterations. The middle and right graphs show prior (green lines) and posterior (grey histograms) density functions for accumulation rate and memory. (For interpretation of the references to color in this figure legend, the reader is referred to the web version of this article.) range than in SU1. Sediments are silt-dominated with values between 39 and 65\% (mean: 57\% \pm 13.0). Compared to SU1, clay admixtures (mean: $26 \% \pm 8.5$ ) are elevated and the sand content is lower (mean: $16 \% \pm 22.2$ ).

SU3 (3120 cal yrs BP to 2012 CE) is characterized by high TOC values between 17.8 and $39.0 \%$ (mean: $30.2 \% \pm 5.0$ ), high $\mathrm{C} / \mathrm{N}$ ratios between 16 and 30 (mean: $22 \pm 3.1$ ), and low $\delta^{13} \mathrm{C}$ between -29.1 and $-26.9 \%$ (mean: $-27.8 \%$ ). This indicates good preservation of fresh and young organic material. $\mathrm{C} / \mathrm{N}$ ratios are roughly constant until the base of the observed active layer. After reaching the maximum, $\mathrm{C} / \mathrm{N}$ decreases again before it reaches a secondary maximum toward the surface. The water content basically follows the curve propagation of TOC from 3120 cal yrs BP until today. In parts older than 3120 cal yrs BP the water content is more variable. The silt fraction amounts to a mean value of $47 \%( \pm 8.5)$; clay admixtures are decreased (mean: $16 \% \pm 6.4$ ) and sand admixtures (mean: $38 \% \pm 13.5$ ) are higher compared to SUs 1 and 2 .

Below the base of the observed active layer at $32 \mathrm{~cm}$ below surface, we found the base of the long-term active layer at ca. $42 \mathrm{~cm}$ below surface, visible as a change in cryostructures, stable water isotope characteristics (see section 5.3) and in water content that increased from $86 \%$ above to $91 \%$ below this boundary (Fig. 5). Waterlogging at the permafrost table and a minimum in $\delta^{13} \mathrm{C}$ of $-28.1 \%$ suggest inhibited OM degradation. TOC and $\mathrm{C} / \mathrm{N}$ are generally related to each other with parallel curve propagation; especially in SU1. The $\mathrm{C} / \mathrm{N}$ ratios generally increase bottom-up, with a maximum at the base of the observed thaw depth.

In summary and based on the studied sediment proxies we assume lacustrine conditions of a thermokarst lake between about 4950 and 3950 cal yrs BP (SU1), mainly based on OM signatures in a $\mathrm{C} / \mathrm{N}-\delta^{13} \mathrm{C}$ biplot indicating lacustrine algae with low $\mathrm{C} / \mathrm{N}$ and isotopically lighter $\delta^{13} \mathrm{C}$ (Fig. S2). After a proposed single event or repeated lake drainage at 3950 cal years BP, a transition unit towards terrestrial conditions is reflected by increasing $\mathrm{C} / \mathrm{N}$ and lower $\delta^{13} \mathrm{C}$ in SU2, which accumulated between about 3950 and 3120 cal yrs BP. Since 3120 cal yrs BP until today, terrestrial signatures of $\mathrm{C} 3$ plants with $\mathrm{C} / \mathrm{N}$ mainly $>20$ and high TOC contents prevail in SU3 (Fig. 5). However, the long-term active-layer depth at about $42 \mathrm{~cm}$ below surface altered the OM decomposition and consequently the $\mathrm{C} / \mathrm{N}$ and $\delta^{13} \mathrm{C}$ composition.

\subsection{Stable water isotopes of pore water and intrasedimental ice}

Stable water isotopes structure the record into two isotope units (IU, Fig. 6) that are separated by a transition zone between the base of the long-term active layer and the observed active layer. IU1 (4950-2350 cal yrs BP) is characterized by increasing $\delta^{18} \mathrm{O}$ and $\delta \mathrm{D}$ values bottom-up; from -18.2 to $-14.0 \%$ and from -143 to $-116 \%$, respectively. This is accompanied by decreasing $d$-excess values from +3.5 to $-7.0 \%$.

IU2 (2350 cal yrs BP to $2012 \mathrm{CE}$ ) is characterized by decreasing $\delta^{18} \mathrm{O}$ and $\delta \mathrm{D}$ values towards the surface; from -14.0 to $-17.6 \%$ and from -116 to $-127 \%$, respectively. This is accompanied by increasing $d$-excess values from -7.0 to $+14.2 \%$. Near the surface we see a typical evaporation signal with a sudden increase in heavy isotopes accompanied by a drop in $d$-excess (Fig. 6).

\subsection{Pollen and plant macrofossils}

The pollen diagram is subdivided into four pollen zones (PZs) based on changing pollen taxa composition and abundances (Fig. 7, SOM). The pollen record is dominated by Cyperaceae, Poaceae, Alnus and Betula. Ranunculaceae, Ericales and Salix. Ferns and Sphagnum contribute most to spore percentages. Non-pollen palynomorphs (NPPs) are mostly represented by algae 


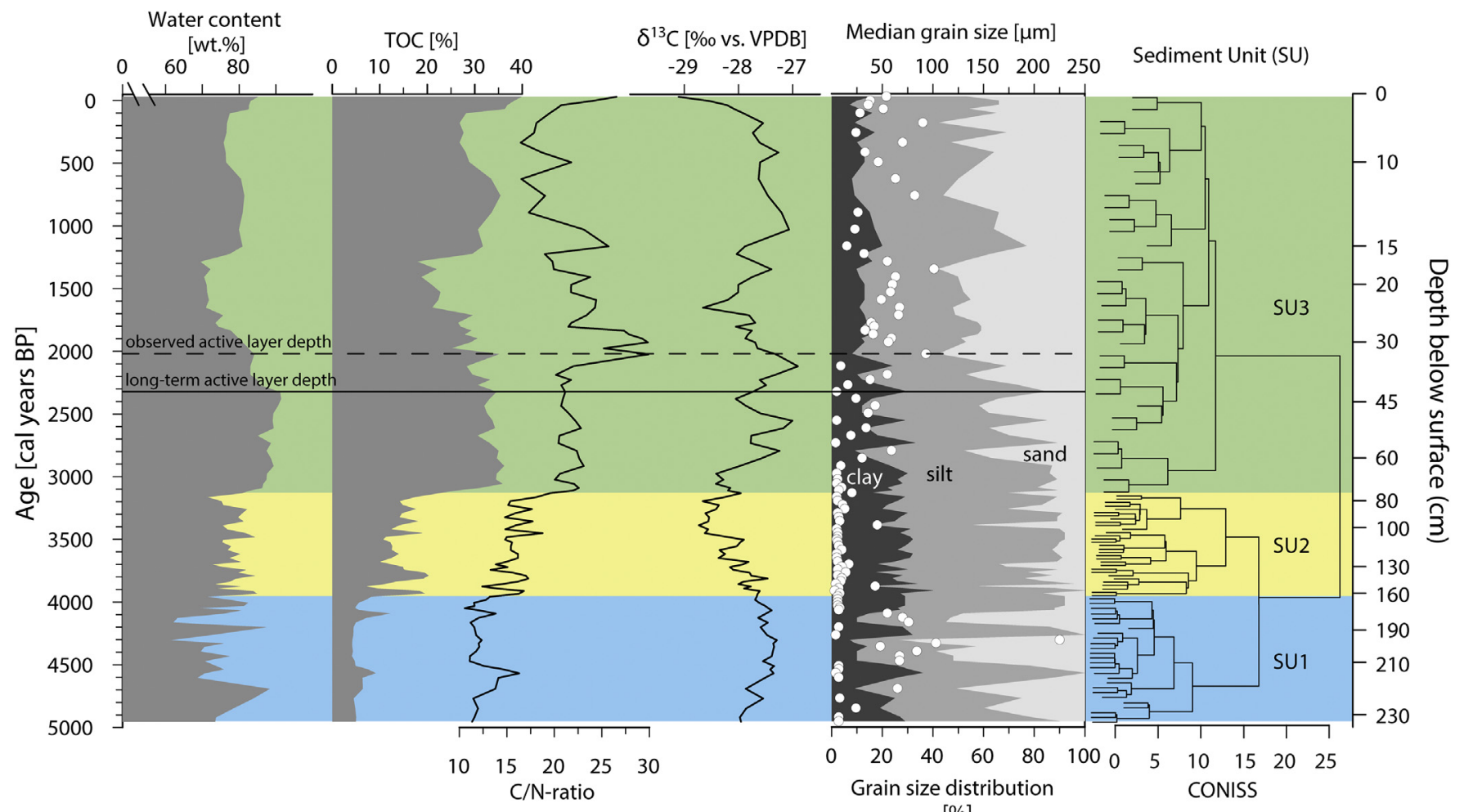

[\%]

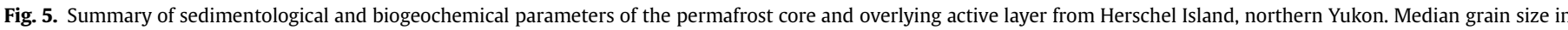

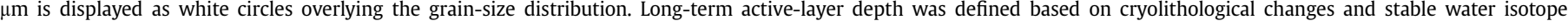
properties (see Fig. 6).

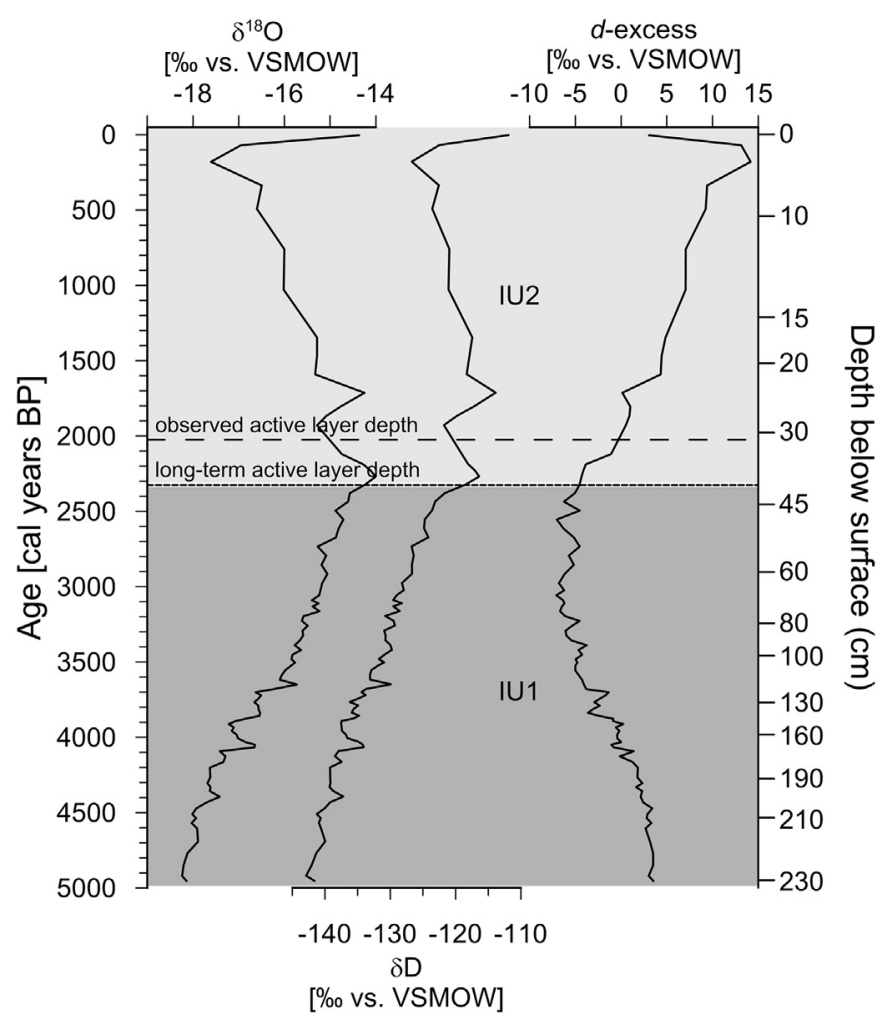

Fig. 6. Stable water isotope parameters $\left(\delta^{18} \mathrm{O}, \delta \mathrm{D}\right.$ and $d$-excess) plotted against age. Long-term active-layer depth, which separates the record into two distinct isotope units (IU), was defined based on cryolithological changes and stable water isotope properties.
(Botryococcus, Cosmarium and Zygnemataceae). The plant macrofossil record shows a shift from emergent aquatic taxa to wetland taxa that occurs at the boundary between sediment units SU2 and SU3 (Table 2).

PZI (4950-4500 cal yrs BP) is characterized by highest abundance of Poaceae throughout the core (up to 50\%). Cyperaceae, Alnus and Betula occur equally with about 15-20\%. Plant macrofossils occur in very low quantities in this zone.

In PZII (4500-3850 cal yrs BP) Cyperaceae become increasingly dominant (up to 40\%), and Poaceae percentages decrease notably. Alnus and Betula remain relatively constant. The macrofossil record is dominated by emergent aquatics (Hippuris sp., Potentilla palustris) and remains of aquatic animals (Trichoptera cases, Daphnia resting eggs). Carex seeds and occasional dwarf shrub remains occur. Both PZI and PZII contain significant amounts of Sphagnum spores if compared to the upper pollen zones. Sphagnum leaves are found in PZ I-III.

PZIII (3850-2950 cal yrs BP) is characterized by a significant increase in Salix pollen (up to 20\%) and by a slight increase in Cyperaceae. Plant material becomes more abundant in this zone, but identifiable seeds and leaves are rare. Aquatic plant macroremains decrease but are still present.

PZIV (2950 yrs BP to 2012 CE) is characterized by a sharp increase in Cyperaceae percentage (up to 62\%) and a decrease in Poaceae. Alnus increases in comparison to PZI-III. Ericales and Sphagnum decrease (Fig. 7). There is an increase to nearly $100 \%$ plant material in core samples from PZIV. Aquatic plant macroremains are absent in this zone and wetland taxa (Carex sp., Eriophorum vaginatum, various dwarf shrubs) become more abundant (Table 2). The upper two plant macrofossil samples at $7-8 \mathrm{~cm}$ and $15-16 \mathrm{~cm}$ below surface consist nearly exclusively of sedge peat. No identifiable seeds or leaves are present in those samples. 


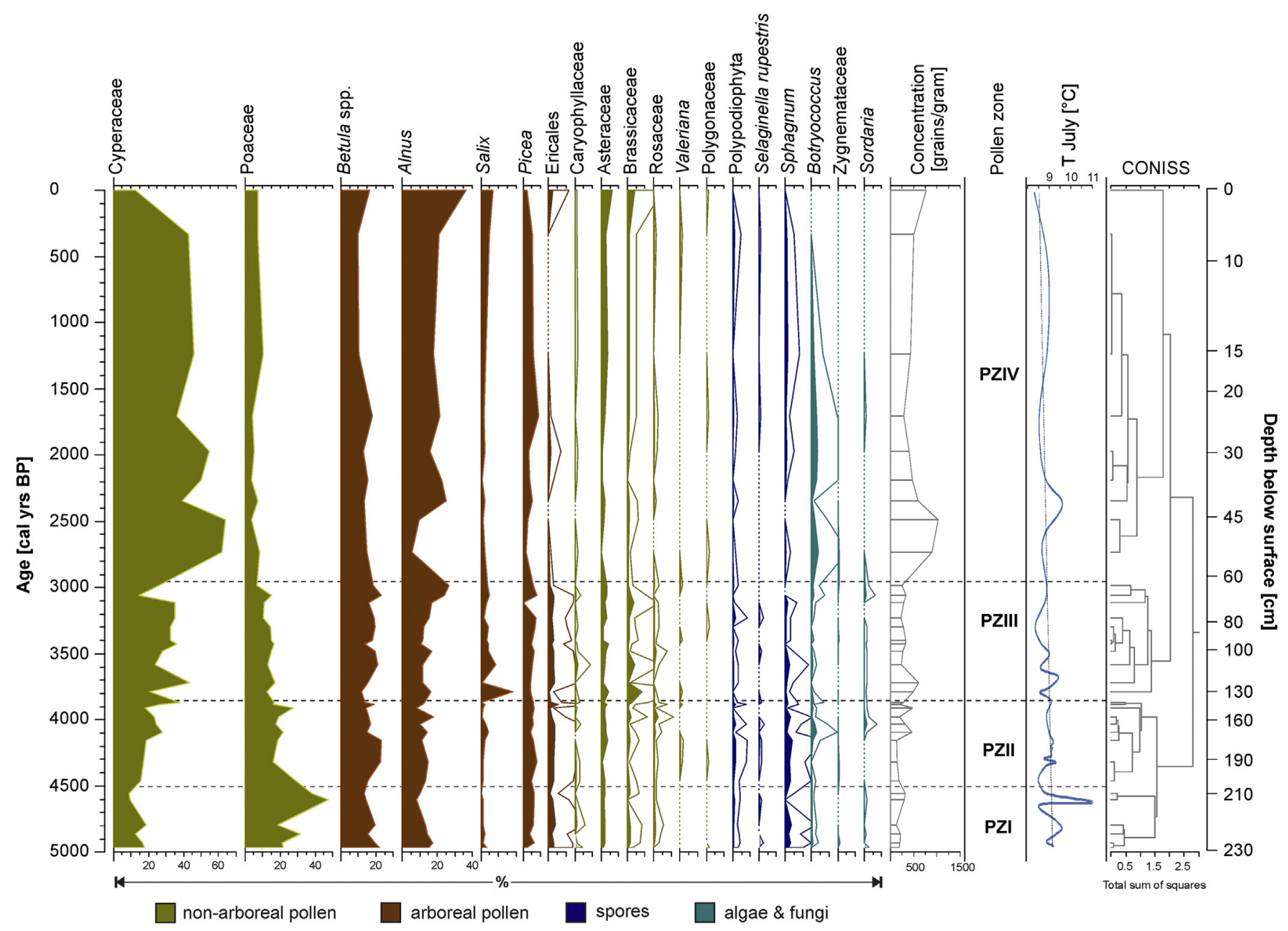

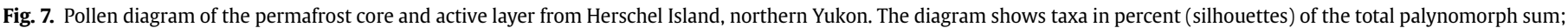

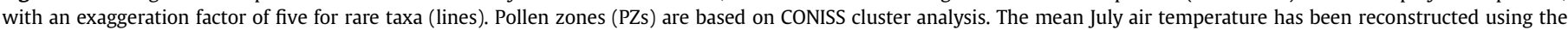
modern analogue technique. The complete counting protocol can be found in the supplementary online material (SOM) to this article.

\subsection{Diatoms}

The diatom diagram summarizes the most abundant and ecologically relevant taxa (Fig. 8). It also shows reconstructed $\mathrm{pH}$ and total phosphorus (TP), and the results of the PCA, and is subdivided into two diatom zones (DZs) based on diatom taxa composition and abundances. The overall ecological characterization of the diatom assemblage is summarized in Fig. 9. The first two PCA axes capture $57.1 \%$ (axis 1: $47.2 \%$, axis 2: 9.9\%) of the total variance in the diatom data, while mainly the first axis reflects the dispersion of diatom types in the ordination diagram (Fig. 8). Ordination of samples to PCA1 matches the zonation obtained by cluster analysis. The boundary between DZI and DZII is located in sediment unit 2 (SU2, Fig. 5) which was outlined as a transition zone from lacustrine towards palustrine conditions.

DZI (4950-3500 cal yrs BP) is characterized by a relatively high diversity, with a taxa number between 32 and 43 per sample. Although benthic species dominate the whole record, benthicplanktonic, alkaliphilic and halophilic species reach highest overall numbers in DZI (Fig. 9) indicating lacustrine conditions. The presence of Fragilaria pinnata and F. construens in DZI points towards warm conditions and an extended open-water period. In the upper part of DZI, a gradual replacement of halophilic Fragilaria pinnata by halophobic F. leptostauron and Cymbella gracilis, and the appearance of the cold-water species Pinnularia brevicostata and Eunotia praerupta point to stagnant water and a gradual decrease in water level, temperature and salinity. Reconstructed $\mathrm{pH}$ ranges from 6.2 to 7.5, which is consistent with the dominance of alkaliphilic diatom species. Reconstructed total phosphorus (TP) concentration ranges from 1.6 to $2.0 \mu \mathrm{g} \mathrm{L} \mathrm{L}^{-1}$ and indicates ultraoligotrophic lake conditions (Reynolds, 2003).

DZII (3500 cal yrs BP to $2012 \mathrm{CE}$ ) is characterized by decreasing species diversity from 46 to 19 . Benthic forms increase, benthicplanktonic species decrease and purely planktonic forms are rare (Fig. 9). The arctic-alpine and cosmopolitan species Cymbella gracilis, C. tynnii, Gomphonema lagerheimii, G. clavatum, Pinnularia subcapitata, Eunotia bilunaris, and especially cold-water taxon E. praerupta are common (Fig. 8). These changes in dominant diatoms indicate ongoing cooling, water-level decrease, and acidification. The highest proportion of cold-water, halophobic, acidophilic and arctic-alpine species occurs in DZII. The reconstructed $\mathrm{pH}$ ranges from 6 to 6.9. TP varies from 0.9 to $2.0 \mu \mathrm{g} \mathrm{L}^{-1}$ and thus indicates ultraoligotrophic conditions. The sample scores of PCA axis 1 summarize the major shifts in the diatom assemblage, reflecting a shift from lacustrine conditions of a thermokarst lake to wetland conditions in an IWP mire with acidification upon peat growth (Fig. 8). 
Table 2

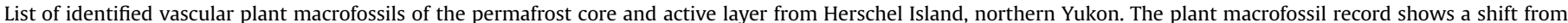

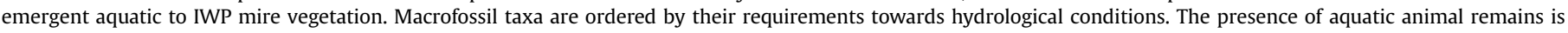
indicated $(\mathrm{x})$.

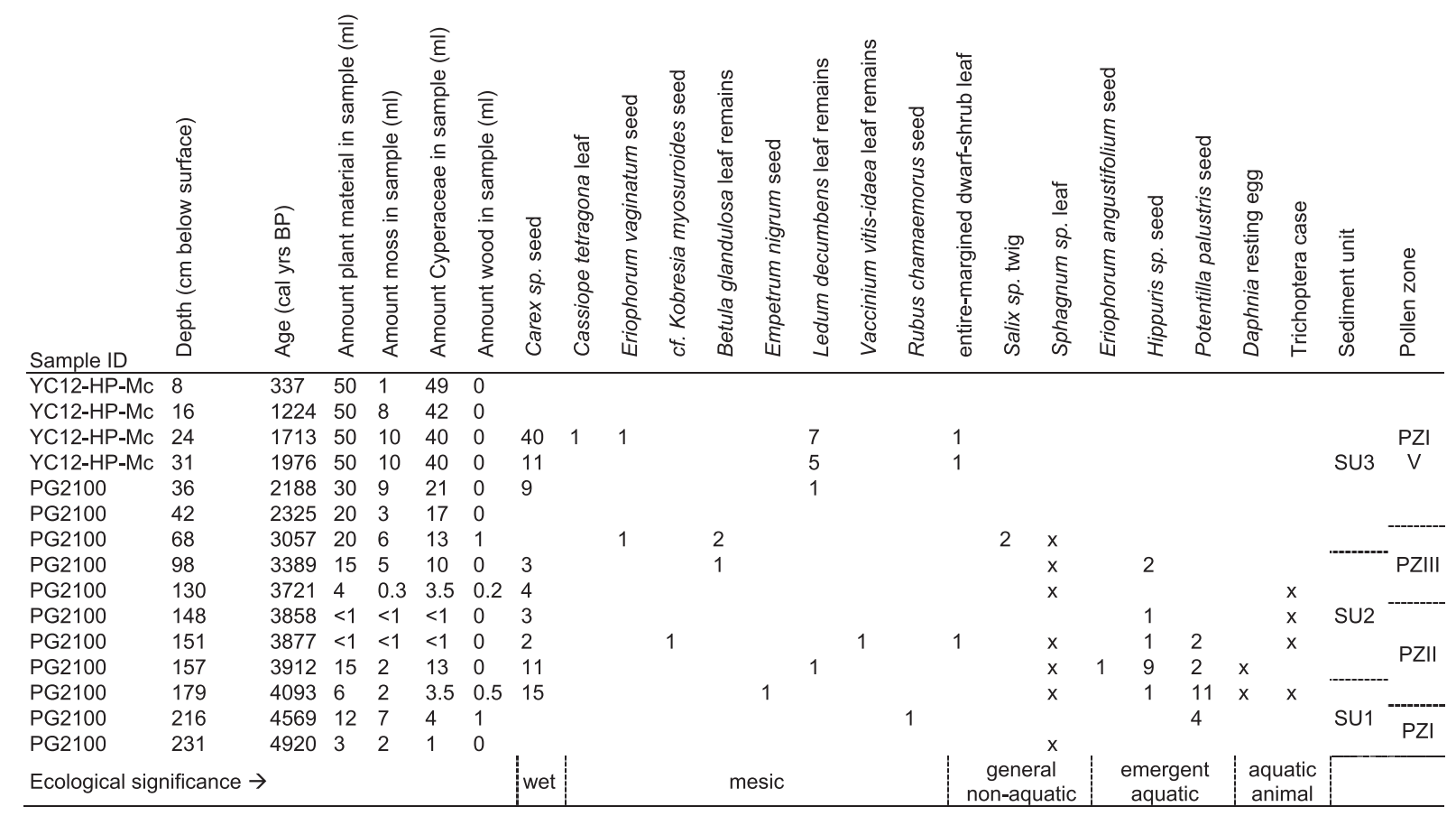

\section{Discussion}

\subsection{IWP development over time}

\subsubsection{Stage 0: pre-lake stage (pre-Holocene)}

Herschel Island and the Yukon Coastal Plain are known to host ice-rich permafrost deposits containing various types of ground ice (Rampton, 1982; Pollard, 1990; Fritz et al., 2012a). Moraines within the Late Wisconsin Laurentide ice limit are often ice-cored with buried glacier ice and massive segregated ice (French, 1998; Fritz et al., 2011). This leads to locally highly variable ground-ice contents in fine-grained, matrix-based diamictons (Fritz et al., 2012a). Differential thaw after deglaciation of the Herschel Island moraine ridge and formerly glaciated parts of the adjacent Yukon Coastal Plain led to thaw subsidence and thaw-basin development (Lenz et al., 2013), especially because of increased summer warmth during the Holocene thermal maximum (Burn, 1997; Kaufman et al., 2004). Thaw basins often host shallow thermokarst lakes as presented in SU1 of our record (see section 6.1.2).

\subsubsection{Stage 1: thermokarst lake stage ( $>4950$ to 3950 cal yrs BP)}

Our hypothesis that a shallow thermokarst lake existed in the modern IWP field is supported by topographic constraints (see Fig. 3a, b). The modern IWP field is located in a shallow basin that is surrounded by a rim of approximately two meters above the bottom elevation of the current IWP field (see Fig. 3a, b). The onset of thermokarst in the northern Yukon is dated toward the Pleistocene-Holocene transition, with a minimum age of 11,200 cal yrs BP of thaw lake deposits on the Yukon mainland coast (Fritz et al., 2012a). Therefore, the age of the studied lake basin ranges between about 11,200 and older than 5000 cal yrs BP, the latter being the oldest date obtained in the present record. This is supported by a peak in basal ages of thermokarst lakes in northwest Canada and Alaska during the Holocene thermal maximum (Rampton, 1988; Brosius et al., 2012).

Throughout our pollen record, the proportion of long-distance transported (e.g. Picea, Alnus), to regional (e.g. Betula, Poaceae, some herbs) and local pollen taxa and groups (Ericales, Cyperaceae, Poaceae, herbs, spores and NPPs) varies. Our pollen-based reconstruction of past vegetation takes into account that pollen data derived from lake and IWP deposits represent different signal sources and spatial scales, and therefore carry different paleoenvironmental information.

SU1 matches PZI to PZII, which are characterized by relatively low pollen concentrations, high percentages of Poaceae, Sphagnum and Ericales, and relatively low Cyperaceae percentages (Fig. 7). Minimum values in the ratio between Cyperaceae and Poaceae (Fig. 10) reflect the regional vegetation that produced pollen collected in the lake deposits. Reconstructed mean July air temperatures yielded values of around $9{ }^{\circ} \mathrm{C}$, which is comparable to modern climate conditions in the area. Although the pollen record does not reveal any aquatic markers, indirect evidence for open water is deduced from the constant presence of the freshwater green algae Zygnema that occurs in limnic habitats (ditches, ponds and lakes; Wehr and Sheath, 2003). Very few plant macrofossils are present in the oldest (lower) part of SU1 (Table 2), which is expected in a lake part that lacks marginal vegetation (distal to shore), because macrofossils are generally locally distributed (Birks, 1980). Remains of Carex sp. and the emergent aquatics Hippuris sp. and Potentilla palustris dominate the macrofossil record towards the younger (upper) part of SU1. The two species indicate shallow water only up to $0.4 \mathrm{~m}$ deep (e.g. Spetzman, 1959) and point to 


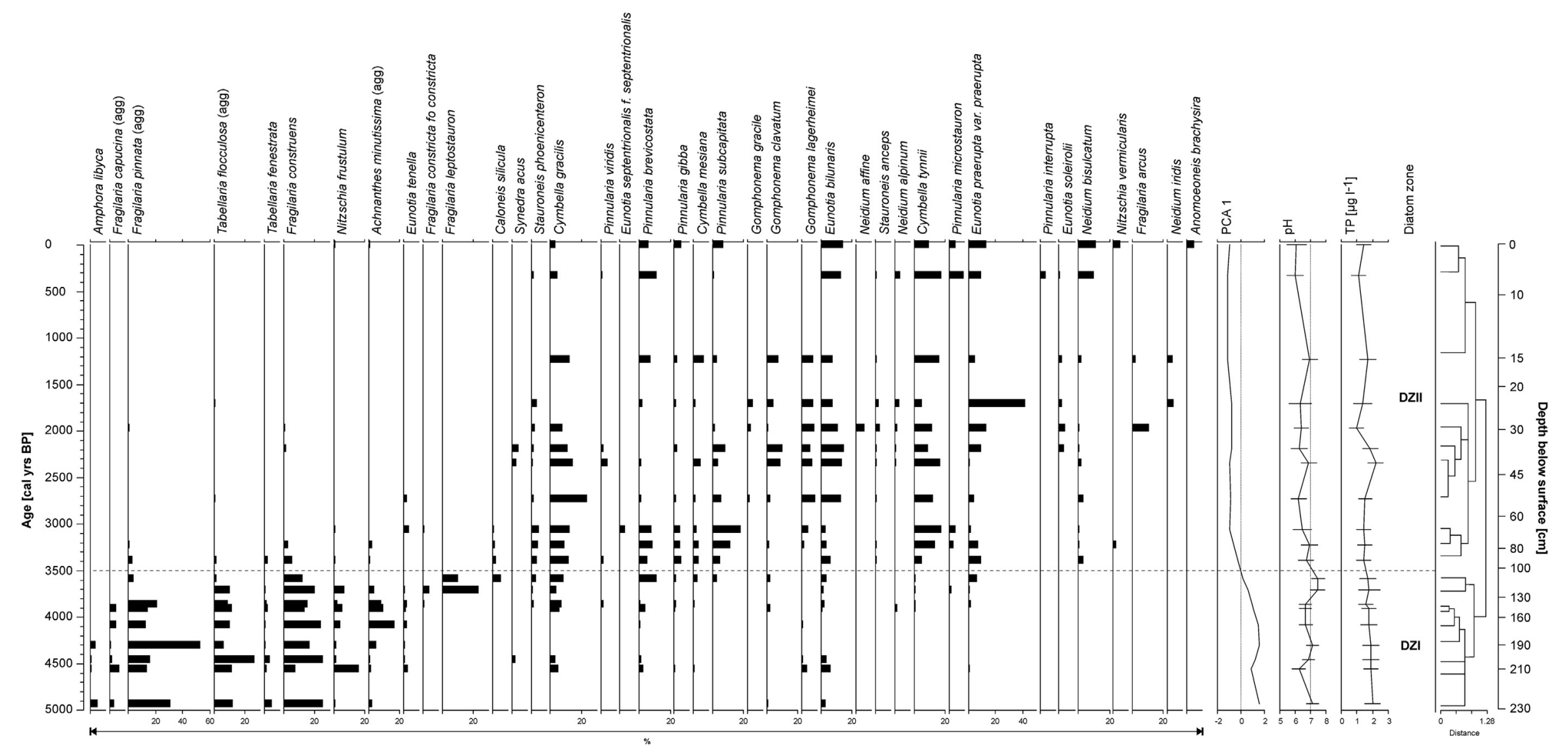




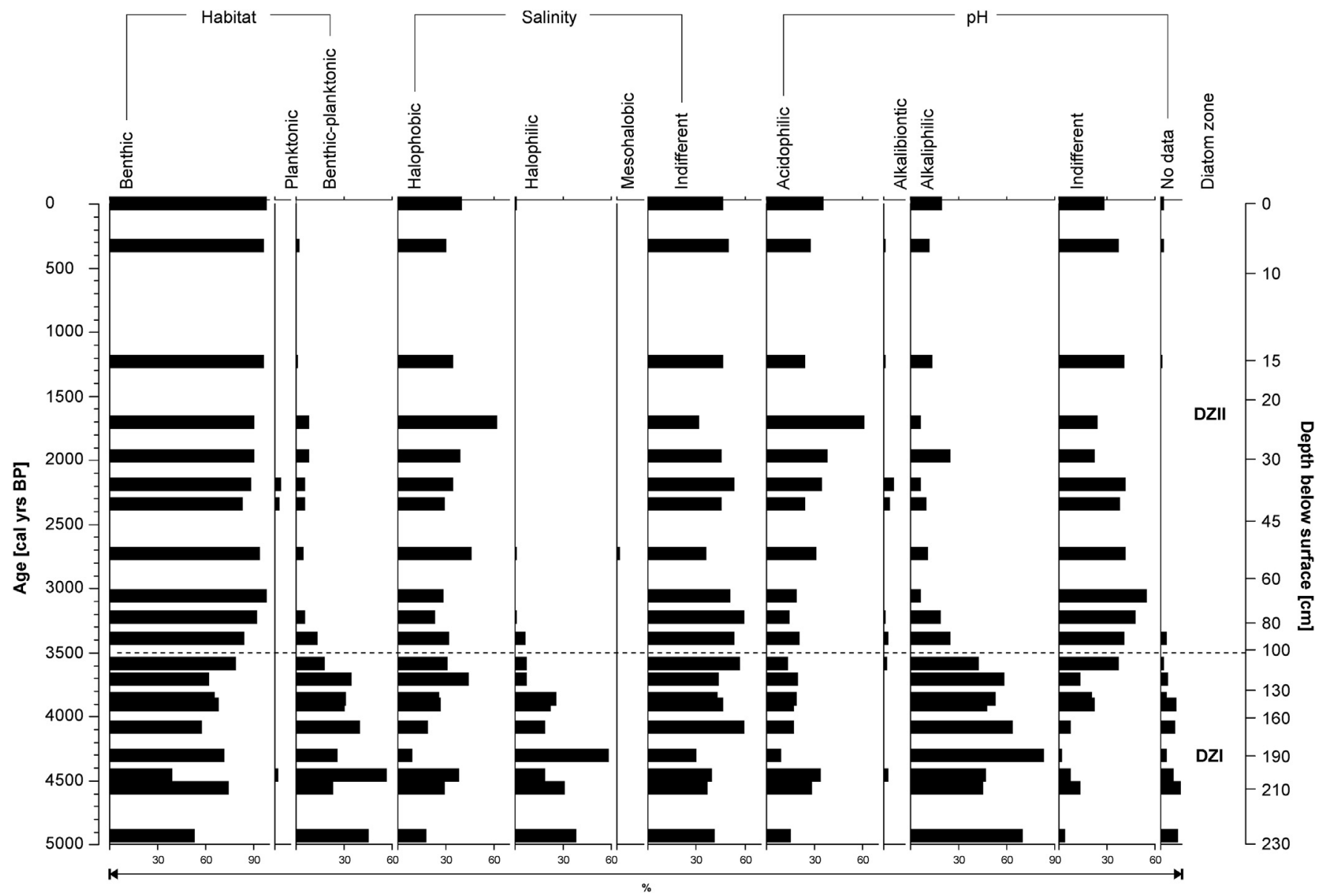

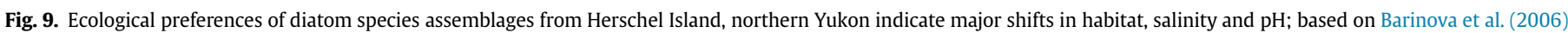

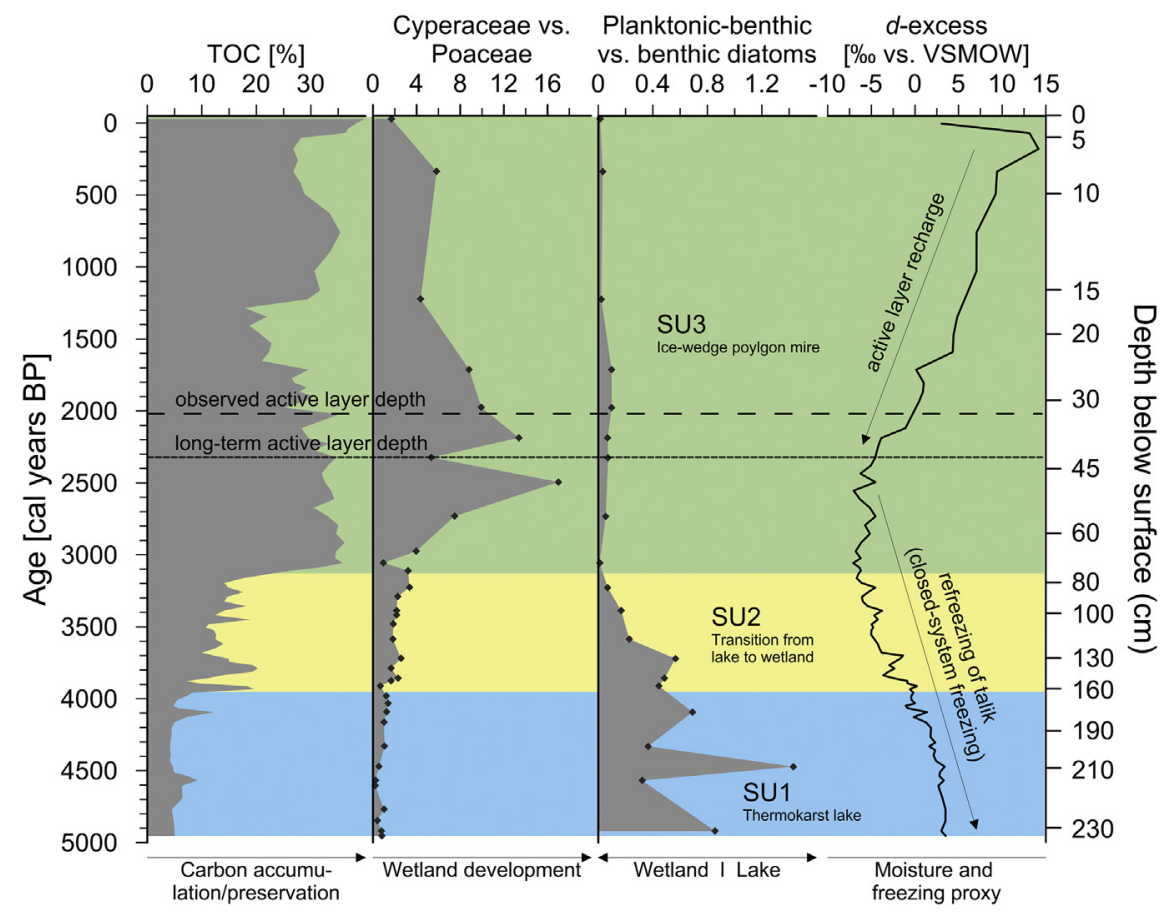

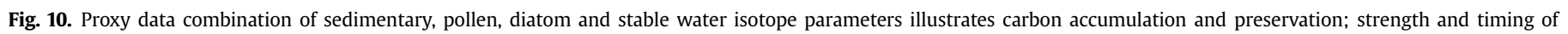
hydrological change; timing of different stages of landscape development; and permafrost conditions. 
water-level decrease and/or developing lake margin vegetation. The diatom record (DZI) indicates open water and considerable water depth by the abundance and dominance of planktonicbenthic diatom species such as Tabellaria flocculosa, Fragilaria construens var. construens. The ratio of planktonic-benthic to benthic diatoms is highest (Fig. 10) in DZI, which also indicates lacustrine conditions. The ecology of the diatom assemblage supports alkaline lake water conditions (Fig. 9) although the numerical $\mathrm{pH}$ reconstruction (Fig. 8) does not show distinct variation between DZI and DZII. Higher salinity as deduced from halophilic diatom species in DZI is typical for modern thermokarst lakes on Herschel Island (Lenz et al., 2013), and originates from ground-ice melt of salty marine morainic deposits in which thermokarst lakes develop. Finally, sedimentary parameters exhibit a lacustrine algae signature in terms of $\mathrm{C} / \mathrm{N}(<15)$ and $\delta^{13} \mathrm{C}(-28.0$ to $-27.3 \%$ ) (cf. Meyers, 1994) between 4950 and 3950 cal yrs BP (Fig. S2) and support lacustrine conditions during accumulation of SU1.

\subsubsection{Stage 2: Lake drainage (at 3950 cal yrs BP)}

The thermokarst lake drained almost completely at about 3950 cal yrs BP and disrupted the lacustrine setting. TOC and C/N approach minimum values indicating OM degradation. Cluster analysis based on $\mathrm{TOC}, \mathrm{C} / \mathrm{N}$ and $\delta^{13} \mathrm{C}$ gives a clear split at 3950 cal yrs BP (Fig. 5). Thermokarst lakes commonly drain suddenly; and sometimes catastrophically (Mackay, 1986; Jones et al., 2011, 2012; Jones and Arp, 2015). We suggest lake drainage as the process associated with the split in the record because of gully incision from southerly direction. Mackay (1981) pointed out that melt out of ice wedges is the most common reason to drain thermokarst lakes. Today, the incising drainage channel intersects two plateaus to the east and west and is clearly following the path of melted ice wedges (Fig. 3a, b).

Reasons for thermokarst lake drainage are multifaceted. Jones et al. (2011) have summarized typical thermokarst lake drainage mechanisms in continuous permafrost, which are all site-specific, such as ice wedge degradation, coastal erosion, lake tapping, stream erosion, development of a drainage network, bank overflow, as well as expansion of a lake toward a drainage gradient. In discontinuous permafrost areas, however, Smith et al. (2005) have invoked climate warming and the creation of open taliks to be responsible for the widespread disappearance of lakes by drainage to the subsurface. In the northern Yukon, relatively stable conditions in terms of summer air temperature and annual precipitation since the middle Holocene, which are based on pollen-climate transfer functions (Fritz et al., 2012b), preclude climate as a major reason for lake drainage.

\subsubsection{Stage 3: mire development and ice-wedge cracking} (3950-3120 cal yrs BP)

After lake drainage, a shallow wetland remained, which is a common phenomenon (see Mackay, 1981). Epiphytic and shallowwater diatoms such as Eunotia and Cymbella species indicate at least permanently wet conditions if not small remaining water bodies in subbasins of the former continuous lake basin. The diatom assemblage gradually changed to be dominated by benthic, acidophilic and halophobic species (Fig. 9). Persisting wet conditions led to the establishment of a transition phase between lacustrine (in sensu stricto) and terrestrial palustrine conditions in a developing IWP peatland accompanied by acidification of the water body due to peat growth. We interpret the increased percentages of Salix and Brassicaceae pollen in this zone as an indication of drained lake revegetation on highly disturbed ground. The most pronounced peaks in Salix and Brassicaceae occur around 3800 cal yrs BP. At the Illisarvik drained lake site, Salix and Brassicaceae had recolonized the site within 7 years after drainage (Ovenden, 1986).
Salix is often among the first species to recolonize disturbed ground because of its rapid growth and high seed production (Forbes and Jefferies, 1999). Brassicaceae, represented by Descurainia in Illisarvik (Ovenden, 1986), are also part of the pioneer vegetation after disturbance. We also observed a slight increase in Cyperaceae and a concomitant decrease in Poaceae, which might reflect the shift from a regionally derived pollen signal toward representation of local wetland vegetation. We assume that since lake drainage the pollen spectrum has the potential to capture a local pollen signal from the surrounding peat and moss polsters rather than being representative of a regional summer temperature and annual precipitation signal (De Klerk et al., 2014; Zibulski et al., 2013). This is useful for the reconstruction of local vegetation change following morphological and hydrological change in IWP mires (De Klerk et al., 2009). De Klerk et al. (2014) studied the recent pollen and modern vegetation assemblage of an IWP in NE Siberia and identified several groups of (i) pollen types representing regional and extraregional taxa, (ii) pollen types produced by local vegetation, and (iii) non-pollen palynomorphs and pollen from plants being present in the specific IWP. Our study supports that pollen records from arctic peatlands mainly reflect short-distance vegetation patterns.

Local conditions are best reflected by plant macrofossils, which are dominated by remains of emergent aquatic plants (Table 2). The presence of Daphnia resting eggs and Trichoptera cases further proves the continued presence of a water body. Occasional remains of plants associated with mesic conditions (e.g. on elevated areas within wetlands) suggest that those plants have been growing close to a water body. Sediment parameters follow this transition towards a terrestrial signature in terms of $\mathrm{C} / \mathrm{N}$-ratios, which increase from 15 to 20 , and in terms of $\delta^{13} \mathrm{C}$ values, which decrease from -27.5 to $-28.7 \%$ (Fig. S2). TOC values also show an increasing trend and, together with increased $\mathrm{C} / \mathrm{N}$-ratios and lower $\delta^{13} \mathrm{C}$ values, indicate increased $\mathrm{OM}$ accumulation and preservation (Fig. 10)

Shortly after drainage, ice-wedge cracking in winter was possible (cf. Mackay, 1986). With similar dimensions to our drained lake basin, we can compare our paleoenvironmental implications with the modern analogue of Lake Illisarvik in the Tuktoyaktuk Coastlands, which was artificially drained in 1978 for the purpose of a long-term study on the growth of permafrost and periglacial features on the newly exposed drained lake bottom (Mackay, 1981). The former Lake Illisarvik was about $600 \mathrm{~m}$ long, $350 \mathrm{~m}$ wide and had a maximum depth of $5 \mathrm{~m}$. At the time of drainage, the talik below the lake center was $32 \mathrm{~m}$ deep (Burgess et al., 1982). Already in the first winter after drainage of Lake Illisarvik, thermal contraction cracking had started and the predominant orientation of the first primary cracks was normal to the topographic contour (Mackay and Burn, 2002). We see a similar crack pattern at our study site with cracks normal to the contour, which are possibly primary cracks, whereas the possibly secondary cracks are aligned along the contour (Fig. 3a). At Illisarvik, cracks also propagated into the ice of a frozen residual pond and re-opened along the same line in succeeding winters (Mackay and Burn, 2002). Mackay (1988) concluded that repetitive cracking along the same line in pond ice proves that the cracks originate in wedge ice below the pond and then propagate both upward and downward. In contrast to the Illisarvik site, where crack activity diminished rapidly and finally ceased due to an increase in winter ground temperatures as vegetation cover began to trap snow (Mackay, 1986), we infer an incomplete drainage with extensively standing water or with at least permanently wet conditions that promoted ice-wedge cracking, because of the persistent presence of epiphytic and shallow-water diatoms (Cymbella gracilis, C. tynii, Eunotia bilunaris, E. praerupta), and the presence of macrofossils of emergent aquatic 
plants (Hippuris sp. and Potentilla palustris).

\subsubsection{Stage 4: IWP succession (3120 cal yrs BP to 2012 CE)}

Since 3120 cal yrs BP the IWP mire is characterized by continuous peat growth and organic carbon sequestration. Obu et al. (2015) have shown that carbon storage in the uppermost meter below the surface on Herschel Island is highest in IWP peatlands with 79-91 $\mathrm{kg} \mathrm{C} \mathrm{m}^{-2}$. Water logging and anaerobic conditions promote organic matter preservation, which make IWP peatlands an important and vulnerable carbon sink throughout the terrestrial Arctic. Low accumulation rates in the uppermost part of the peat sequence, which corresponds to the last 2000 years (Fig. 4), accompanied by decreasing $\mathrm{C} / \mathrm{N}$ ratios indicate reduced organic matter production and/or preservation (Fig. 10). This could be related to climatic cooling (Wanner et al., 2008) and drier conditions in the late Holocene (Pienitz et al., 2000) together with low compaction of the uppermost decimeters. In northern Alaska, Eisner and Peterson (1998a) have attributed declining peat accumulation rates to increased nutrient stress as permafrost aggradation immobilized mineral nutrients. In northwest Canada, Vardy et al. (1998) suggested that late Holocene regional cooling led to establishment of ombrotrophic (i.e. nutrient-poor) conditions, associated with the enhanced aggradation of permafrost in peatlands.

The localized pollen signal indicates that vegetation composition was relatively constant throughout the late Holocene. This in turn implies rather constant local moisture and micromorphology. The dominance of Cyperaceae is typical for wet low-centered IWP. Since peat accumulation started at around 3120 cal yrs BP, Cyperaceae are generally above $40 \%$, and Poaceae $\leq 5 \%$ (Fig. 7 ) as illustrated in the high Cyperaceae/Poaceae ratio (Fig. 10). The palynological record of the last 3000 years also shows increasing percentages of Botryococcus spores. These shallow-water green algae indicate oligotrophic conditions (Jankovská and Komárek, 2000) and are known from fossil IWP centers in eastern Siberia (Wetterich et al., 2011). Botryococcus percentages decrease again towards the top of the core, indicating drier conditions within the IWP. The diatom record (DZII) exhibits prevailing benthic, acidophilic and halophobic species (Fig. 9). The plant macrofossil record shows a mixture of taxa related to both elevated and nonsubmerged low-lying areas in low-centered IWPs (Table 2, Wolter et al., accepted). The absence of emergent aquatic plant macrofossils since 1500 cal yrs BP indicates disappearance of the intrapolygonal pond.

Epigenetic permafrost aggraded in the initial phase of IWP development after lake drainage. Continuous downward refreezing of the talik is indicated as heavy isotopes become progressively depleted, while $d$-excess values concurrently increase (Fig. 6). We argue for closed-system freezing as it has been shown by Fritz et al. (2011) in ground ice. First, the $\delta \mathrm{D}-\delta^{18} \mathrm{O}$ regression slope of 4.88 $\left(\mathrm{R}^{2}=0.97\right)$ in the permafrost core is well below the global $(8.0)$ and the local meteoric water lines (7.3) (Fig. 11a). Second, we see a negative correlation between $d$-excess and $\delta \mathrm{D}$ (Fig. 11b) as it is expected during equilibrium freezing (Souchez et al., 2000).

Interestingly, increasing $\delta \mathrm{D}$ and $\delta^{18} \mathrm{O}$ values together with a decreasing $d$-excess - from the surface towards the base of the long-term active layer (Figs. 6,10 and 11b) - point to a recharge of active-layer material with modern water from precipitation during cold-weather situations. The 'normal' active-layer condition is assumed to be characterized by $\delta^{18} \mathrm{O}$ values of around -15 to $-14 \%$ and $d$-excess values between 0 and $-5 \%$ (Figs. 6 and 10), which is typical for intrasedimental ice of near-surface peat (Vardy et al., 1997, 1998; Fritz et al., 2012a) and surface water in modern thermokarst waters in the area (Fritz et al., 2015). Summer evaporation leads to strong kinetic fractionation in the top-most centimeters
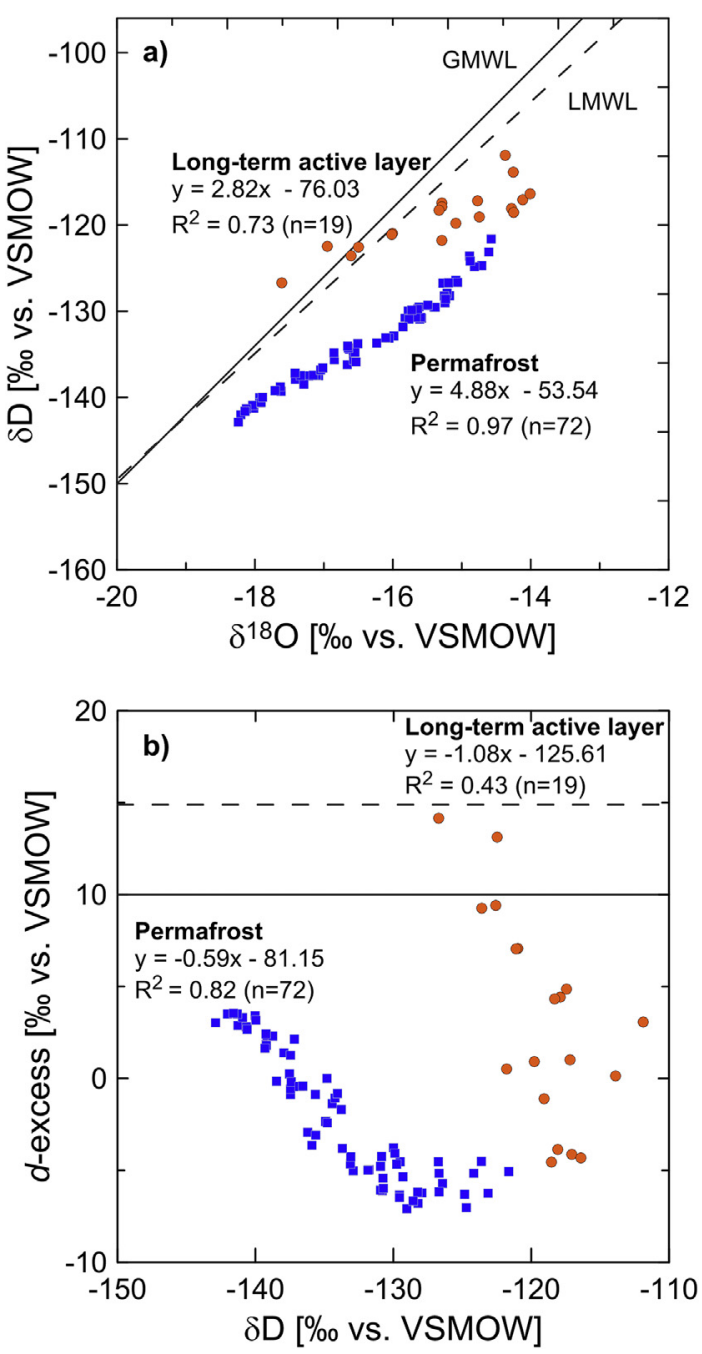

Fig. 11. (a) $\delta^{18} \mathrm{O}-\delta \mathrm{D}$ diagram of permafrost (blue squares) and seasonally frozen (orange circles) material above the long-term active layer from Herschel Island, northern Yukon. Samples in permafrost plot along a $\delta \mathrm{D}-\delta^{18} \mathrm{O}$ regression slope below the global meteoric water line (GMWL: $\delta \mathrm{D}=8 \delta^{18} \mathrm{O}+10$; Craig, 1961) and below the local meteoric water line for Inuvik (LMWL: $\delta \mathrm{D}=7.3 \delta^{18} \mathrm{O}-3.5 ; \mathrm{R}^{2}=0.98$; IAEA, 2015), which is indicative of a freezing slope. (b) Relationship between $\delta \mathrm{D}$ and deuterium excess $(d-$ excess) of permanently frozen deposits and seasonally frozen material above the longterm active layer. The horizontal solid line represents the $d$-excess of the global meteoric water line $(d$-excess $=10)$. The dashed line shows the $d$-excess of the local meteoric water line for Inuvik ( $d$-excess $=14.9$; IAEA, 2015). The negative correlation is indicative of fractionation under closed conditions; i.e. closed-system freezing. VSMOW $=$ Vienna Standard Mean Ocean Water. (For interpretation of the references to color in this figure legend, the reader is referred to the web version of this article.)

which is visible in steeply increasing delta values and a simultaneously decreasing $d$-excess (Figs. 6 and 10).

\subsection{Regional IWP development in NW Canada: review and data synthesis}

\subsubsection{Late Wisconsin IWP development}

Late Pleistocene IWP development in the northern Yukon is not restricted to areas beyond the Late Wisconsin glacial limit. However, fossil indicators of full-glacial IWPs like in other regions of icefree Beringia have not been observed yet. This might be due to the sedimentary environment at the eastern Beringian edge, which was close to the ice margin. An alluvial proglacial environment with high sedimentation rates and frequent flooding by meltwater was 
probably not favorable for ice-wedge formation and preservation (Fritz et al., 2012a). Herschel Island and formerly glaciated parts of the Yukon Coastal Plain became ice-free by about 16,000 cal yrs BP (Fritz et al., 2012a, b). Few remnants of Late Wisconsin ice wedges have been preserved on Herschel Island (Fig. 12c). Small ice-wedge roots likely represent epigenetic ice wedges that have been truncated by a distinct thaw unconformity. Fritz et al. (2012a) reported $\delta^{18} \mathrm{O}$ signatures between -31 and $-26 \%$ for such Late Wisconsin ice wedges, which is $5-7 \%$ lower than those of Holocene ice wedges in the western Canadian Arctic (cf. Mackay, 1983; Burn et al., 1986; Michel, 1990). The limited occurrence of Late Wisconsin ice wedges may have been due to low moisture supply in winter (Kotler and Burn, 2000). Their epigenetic nature might be responsible for the lack of thick peat sections as otherwise prominent syngenetic IWP fillings. Ice-wedge-cast deposits (Fig. 12b) dating back to 11,200 cal yrs BP also indicate that an early phase of IWP formation along the mainland coast occurred prior to the onset of the Holocene (Fritz et al., 2012a). This might be coincident with extensive lateglacial ice-wedge development prior to the end of the Younger Dryas as recorded in the Barrow region in northern Alaska (Meyer et al., 2010).

\subsubsection{Early Holocene IWP degradation and thermokarst}

We propose that a thermokarst lake developed prior to the maximum age of our record. The lake presence can still be seen at the beginning of our record. Initiation of a thermokarst lake in the studied basin and even the basin formation itself could likely have occurred in this period (Lenz et al., 2013). Several studies in northwestern Canada have invoked the early Holocene thermal maximum as a period of increased thermokarst activity and deepening of the active layer (Burn, 1997; Vardy et al., 1997; Fritz et al., 2012a). Ice-wedge-cast deposits dating back until about 11,200 cal yrs BP (Fritz et al., 2012a) indicate an early period of ice wedge degradation and melting (Fig. 12b) at the onset of the Holocene. Ice-wedge growth would have been reduced or absent (Mackay, 1992; Murton and Bateman, 2007; Murton, 2009) during such a period of near-surface permafrost thaw and thermokarst lake development. Active-layer deepening to as much as $1.5-3.0 \mathrm{~m}$ below the modern surface is recorded on Herschel Island and in the western Canadian Arctic by truncated ice wedges and a prominent unconformity (Fig. 12c) due to this greater thaw depth (e.g. Burn et al., 1986; Harry et al., 1988; Murton and French, 1994; Fritz et al., 2012a). Peat growth along Komakuk Beach (Fig. 2) was extensive at least until 6700 cal yrs BP, gradually slowing afterwards (Fritz et al., 2012a). Our findings suggest that the prohibition of ice-wedge formation due to talik formation under a thaw lake can be topographically and geomorphologically constrained (Fig. 3). In this study, lake drainage and subsequent onset of icewedge formation at the drained site was probably caused by channel erosion along degrading ice wedges surrounding the thermokarst lake.

\subsubsection{Middle and Late Holocene IWP mire succession}

Evidence from northwest Canada and northern Alaska indicate permafrost aggradation, re-initiation of ice-wedge growth and thaw lake drainage in response to climate cooling following the Holocene thermal maximum and persisting until the middle of the 20th century (Ritchie, 1984; Mackay, 1992). Today, IWPs west of the

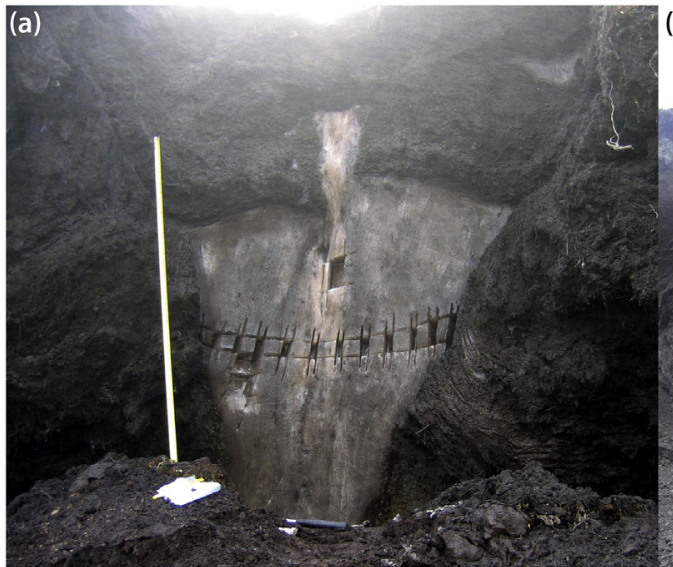

(c) (b)

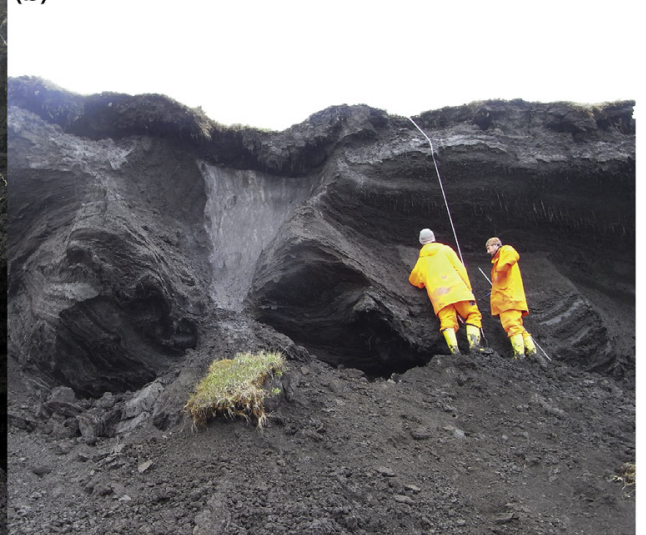

Holocene anti-syngenetic ice wedges

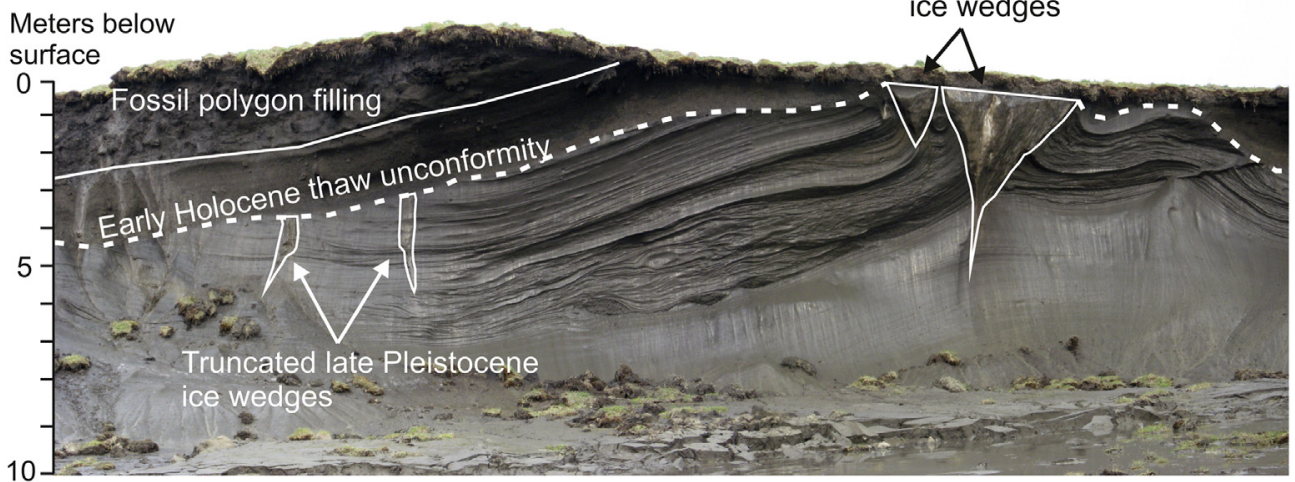

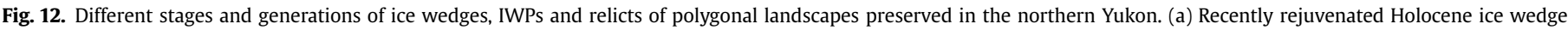

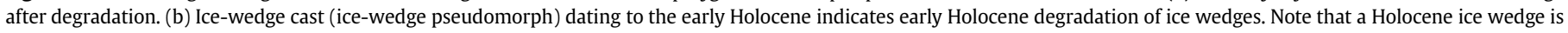
cracking into an older ice-wedge cast. (c) Different stages and ages of ice wedges on Herschel Island and their stratigraphic setting. 
Late Wisconsin glacial limit (i.e. eastern Beringia) are mostly highcentered or flat-centered with signs of degradation (Fig. 1b, c). Icewedge degradation usually causes high-centered IWPs to form so that formerly low-centered IWPs have probably been converted into high-centered IWPs, with improved drainage into the icewedge troughs. In the Tuktoyaktuk Coastlands (Northwest Territories) and in northern Alaska, accumulation rates of organic matter were highest during the early stages of peatland development during the early Holocene, declining after 5000 cal yrs BP (Vardy et al., 1997; Eisner and Peterson, 1998a). In contrast, our record shows sustained high sedimentation rates until 3120 cal yrs BP with material that has substantial inorganic components (Fig. 5). This period corresponds to the thermokarst and wetland stages, when sedimentation in lacustrine and palustrine environments captured significant amounts of sediment from the catchment via running water into the basin center. Based on stable water isotopes and plant macrofossils, Vardy et al. (1998) suggested that reduced accumulation rates were caused by the transition to ombrotrophic conditions in peatlands, possibly related to the aggradation of permafrost, in response to regional cooling. Increasing $\delta^{18} \mathrm{O}$ and decreasing $d$-excess values toward the surface in peat sections at Komakuk Beach (northern Yukon) indicate environmental conditions favorable for an ombrotrophic peatland and surface drying (Fritz et al., 2012a). Lower summer air temperatures in response to a long-term regional cooling (Viau et al., 2008; Bunbury and Gajewski, 2009) and reduced productivity associated with paludification and permafrost aggradation may have led to reduced peat growth and lower carbon accumulation rates during the last 4000 years (Vardy et al., 1997, 2000; Eisner and Peterson, 1998a; Eisner et al., 2005). We would like to note that low accumulation rates in permafrost peatlands are not necessarily or purely climatedriven. Besides low growth rates because of unfavourable climateor site-specific conditions, other factors that can explain low accumulation rates are organic-matter degradation, compaction, and limited ground-ice growth which would induce a volume increase of ca. $10 \%$.

There have been several episodes of IWP degradation and reactivation during the late Holocene. Coastal cliff exposures along the Yukon coast with deeply thawed Holocene ice-wedge surfaces and secondary or even tertiary ice-wedge generations support this view (Fig. 11a). Recent permafrost conditions are probably best explained by the occurrence and size of rejuvenated ice-wedges along the Yukon coast. Here, the tops of primary wedges, which are approximately $1 \mathrm{~m}$ below the surface (Fig. 12a), mark the base of a relict active layer that is possibly a thaw unconformity of unknown age but postdating the Holocene thermal maximum (Fritz et al., 2012a). After this thaw episode, the renewed aggradation of permafrost has led to ice-wedge rejuvenation, indicated by new growth stages extending upward to the modern frost table (Mackay, 1976; Harry et al., 1985). This renewed growth could have either developed in response to a climate cooling trend or to a reorganization of ice-wedge cracking in certain IWPs. Due to the widespread occurrence of rejuvenation in the western Arctic (Mackay, 1976) we consider active-layer thinning in response to climate cooling as a primary mechanism. Viau et al. (2012) inferred from pollen data that the Little Ice Age was cooler than today across all of North America, thereby providing a possible climate framework for ice-wedge rejuvenation. This hypothesis, however, needs to be further tested.

\section{Conclusions}

Paleoenvironmental analyses of frozen peat and underlying lake sediments complemented by findings from the literature allowed the reconstruction of thermokarst, lake drainage and IWP development in the northern Yukon throughout the Holocene. At the onset of the Holocene, thawing of ice-rich permafrost led to thermokarst in the circum-arctic including the degradation of Late Wisconsin ice wedges and the widespread formation of thermokarst lakes. During the last 5000 years a field of mature IWPs developed at the study site on Herschel Island, in a basin that was previously occupied by a thermokarst lake. Changes in diatom and plant macrofossil assemblages indicate a rapid drainage of the thermokarst lake at about 3950 cal yrs BP. Drainage was not directly linked to climate variations but was caused by gully incision which tapped the lake. Reconstructed summer air temperatures based on pollen are similar to modern conditions since the middle Holocene. Aggrading permafrost affected the wetland after drainage, which was successively invaded by terrestrial plant species with an affiliation to wetlands. Repeated ice-wedge cracking led to the closure of polygonal structures and thereby changed the hydrological regime that favored extensive peat formation in a wet low-centered IWP mire. Since 3120 cal yrs BP organic carbon was rapidly incorporated into aggrading permafrost under wet, acidic and lowoxygen conditions. This process makes arctic IWP peatlands in general extensive carbon reservoirs. On the one hand, fossil pollen have recorded a very local vegetation signal since lake drainage, which does not allow any inference about regional climate variations. On the other hand, local vegetation succession and diversity patterns can be inferred, especially in combination with the study of plant macrofossils.

Regional studies of IWPs have shown that different ice-wedge generations in the northern Yukon serve as a paleoenvironmental indicator of certain episodes of Holocene permafrost aggradation. In contrast, ice-wedge casts, thaw unconformities, and truncated ice wedges have recorded episodes of permafrost degradation since the Late Wisconsin. Environmental records from IWP centers and associated ice wedges suggest a high temporal diversity in IWP mire origin. IWP dynamics in the Arctic are defined by a complex array of conditions and feedbacks. Permafrost-specific phenomena such as ice-wedge cracking, thermokarst and refreezing of newlyexposed ground provide the basis for IWP formation and development. IWPs are modified by external forces such as temperature, precipitation or coastal erosion and internal processes such as small-scale changes in topography, morphology, hydrology, and vegetation succession.

\section{Acknowledgements}

We thank the Yukon Territorial Government, the Yukon Parks (Herschel Island Qiqiktaruk Territorial Park), Parks Canada office (Ivvavik National Park) and the Aurora Research Institute - Aurora College (ARI) in Inuvik, NWT, for administrative and logistical support. This study was partly funded by the International Bureau of the German Federal Ministry of Education and Research (BMBF grant № CAN 09/001, 01DM12002 to H.L.) and the Helmholtz Association (grant № VH-NG-801 to H.L.). The study contributes to the Arctic Ecological Network (BMBF grant № 01DJ14003 to S.W.). L.N. and O.P. were sponsored by the Russian Government Program of Competitive Growth of Kazan Federal University and L.N. by the DFG (grant № NA 760/5-1). Analytical work received great help from Ute Kuschel, Tyne Brückner, Izabela Milczarek, and Christin Kramer at AWI and from Heiko Baschek at GeoForschungsZentrum Potsdam, Germany. George Tanski assisted in the field and Stefanie Burmeister assisted in technical preparation of the paper.

\section{Appendix A. Supplementary data}

Supplementary data and figures related to this article can be found at http://dx.doi.org/10.1016/j.quascirev.2016.02.008. 
Data presented in this work are available from the PANGAEA database at http://doi.pangaea.de/10.1594/PANGAEA.856781.

\section{References}

Anderberg, A.L., 1994. Atlas of Seeds and Small Fruits of Northwest-European Plant Species with Morphological Descriptions. Part 4. Resedaceae-Umbelliferae Swedish Museum of Natural History, Stockholm, p. 281.

Andreev, A.A., Schirrmeister, L., Tarasov, P.E., Ganopolski, A., Brovkin, V., Siegert, C., Wetterich, S., Hubberten, H.-W., 2011. Vegetation and climate history in the Laptev Sea region (Arctic Siberia) during Late Quaternary inferred from pollen records. Quat. Sci. Rev. 30, 2182-2199.

Barinova, S., Medvedeva, L., Anisimova, O., 2006. Biodiversity of Algae Indicators of Environment, Tel-aviv, p. 498 (in Russian).

Battarbee, R.W., 1986. Diatom analysis. In: Berglund, B.E. (Ed.), Handbook of Holocene Palaeoecology and Palaeohydrology. John Wiley \& Sons, Chichester, pp. 527-570.

Battarbee, R.W., Juggins, S., Gasse, F., Anderson, N.J., Bennion, H., Cameron, N.G. Ryves, D.B., Pailles, C., Chalie, F., Telford, R., 2001. European Diatom Database (EdDI). An Information System for Palaeoenvironmental Reconstruction, vol. 81, p. 94. ECRC Research Report No.

Bennett, K.D., 1996. Determination of the number of zones in a biostratigraphica sequence. New Phytol. 132, 155-170.

Berggren, G., 1969. Atlas of Seeds and Small Fruits of Northwest-european Plant Species with Morphological Descriptions. Part 2, Cyperaceae. Swedish Nat. Science Res. Council, Stockholm, p. 68.

Berggren, G., 1981. Atlas of Seeds and Small Fruits of Northwest-European Plant Species with Morphological Descriptions, Part 3. Salicaceae-cruciferae. Swedish Museum of Natural History, Stockholm, p. 259.

Beug, H.-J., 2004. Leitfaden der Pollenbestimmung für Mitteleuropa und angrenzende Gebiete. Verlag Dr. Friedrich Pfeil, München, p. 542.

Birks, H.J.B., 1980. Modern pollen assemblages and vegetational history of the moraines of the Klutlan Glacier and its surroundings, Yukon Territory, Canada. Quat. Res. 14, 101-129.

Blaauw, M., Christen, J.A., 2011. Flexible paleoclimate age-depth models using an autoregressive gamma process. Bayesian Anal. 6, 457-474.

Bobrov, A.A., Wetterich, S., Beermann, F., Schneider, A., Kokhanova, L., Schirrmeister, L., Pestryakova, L., Herzschuh, U., 2013. Testate amoebae and environmental features of polygon tundra in the Indigirka lowland (East Siberia). Polar Biol. 36, 857-870.

Bouchard, M., 1974. Géologie des dépôts meubles de l'île Herschel, territoire du Yukon. Thèse (M. Sc.: Géologie). Université de Montréal, p. 70 (in French).

Brosius, L.S., Walter Anthony, K.M., Grosse, G., Chanton, J.P., Farquharson, L.M., Overduin, P.P., Meyer, H., 2012. Using the deuterium isotope composition of permafrost meltwater to constrain thermokarst lake contributions to atmospheric $\mathrm{CH}_{4}$ during the last deglaciation. J. Geophys. Res. 117, G01022.

Brown, J., Ferrians Jr., O., Heginbottom, J., Melnikov, E., 1998. Circum-arctic Map of Permafrost and Ground-ice Conditions. National Snow and Ice Data Center World Data Center for Glaciology, Boulder, CO. Digital media.

Bunbury, J., Gajewski, K., 2009. Postglacial climates inferred from a lake at treeline, southwest Yukon Territory, Canada. Quat. Sci. Rev. 28, 354-369.

Burgess, M., Judge, A., Taylor, A., Allen, V., 1982. Ground temperature studies of permafrost growth at a drained lake site, Mackenzie Delta. In: French, H.M. (Ed.), 4th Canadian Permafrost Conference, Calgary, Alberta, Canada, pp. 3-11.

Burn, C.R., 1997. Cryostratigraphy, paleogeography, and climate change during the early Holocene warm interval, western Arctic coast, Canada. Can. J. Earth Sci. 34, 912-925.

Burn, C.R., Michel, F.A., Smith, M.W., 1986. Stratigraphic, isotopic, and mineralogical evidence for an early Holocene thaw unconformity at Mayo, Yukon Territory. Can. J. Earth Sci. 23, 794-803.

Burn, C.R., Smith, M.W., 1990. Development of thermokarst lakes during the Holocene at sites near Mayo, Yukon Territory. Permafr. Periglac. Process. 1, $161-175$.

Burn, C.R., Zhang, Y., 2009. Permafrost and climate change at Herschel Island (Qikiqtaruq), Yukon Territory, Canada. J. Geophys. Res. 114, F02001.

Couture, N.J., 2010. Fluxes of Soil Organic Carbon from Eroding Permafrost Coasts, Canadian Beaufort Sea. PhD Thesis. McGill University, Department of Geography, p. 155.

Craig, H., 1961. Isotopic variations in meteoric waters. Science 133, 1702-1703.

Dansgaard, W., 1964. Stable isotopes in precipitation. Tellus 16, 436-468.

De Klerk, P., Donner, N., Joosten, H., Karpov, N.S., Minke, M., Seifert, N., Theuerkauf, M., 2009. Vegetation patterns, recent pollen deposition and distribution of non-pollen palynomorphs in a polygon mire near Chokurdakh (NE Yakutia, NE Siberia). Boreas 38, 39-58.

De Klerk, P., Donner, N., Karpov, N.S., Minke, M., Joosten, H., 2011. Short-term dynamics of a low-centred ice-wedge polygon near Chokurdakh (NE Yakutia, NE Siberia) and climate change during the last ca 1250 years. Quat. Sci. Rev. 30, 3013-3031.

De Klerk, P., Teltewskoi, A., Theuerkauf, M., Joosten, H., 2014. Vegetation patterns pollen deposition and distribution of non-pollen palynomorphs in an icewedge polygon near Kytalyk (NE Siberia), with some remarks on Arctic pollen morphology. Polar Biol. 37, 1393-1412.

Dutta, K., Schuur, E., Neff, J., Zimov, S., 2006. Potential carbon release from permafrost soils of northeastern Siberia. Glob. Change Biol. 12, 2336-2351.

Dyke, A.S., Prest, V.K., 1987. Late Wisconsinan and Holocene history of the Laurentide Ice Sheet. Géogr. phys. Quat. 41, 237-263.

Eisner, W.R., Bockheim, J.G., Hinkel, K.M., Brown, T.A., Nelson, F.E., Peterson, K.M., Jones, B.M., 2005. Paleoenvironmental analyses of an organic deposit from an erosional landscape remnant, Arctic Coastal Plain of Alaska. Palaeogeogr. Palaeoclimatol. Palaeoecol. 217, 187-204.

Eisner, W.R., Peterson, K.M., 1998a. High-resolution pollen analysis of tundra polygons from the North Slope of Alaska. J. Geophys. Res. 103 (D22), 28929-28937.

Eisner, W.R., Peterson, K.M., 1998b. Pollen, fungi and algae as age indicators of drained lake basins near Barrow, Alaska. In: Lewkowicz, A.G., Allard, M. (Eds.), Seventh International Conference on Permafrost. Nordicana, Yellowknife, NWT, Canada, 23-27 June, 1998, pp. 245-250.

Ellis, C.J., Rochefort, L., 2006. Long-term sensitivity of a High Arctic wetland to Holocene climate change. J. Ecol. 94, 441-454.

Environment Canada, 2015. http://climate.weather.gc.ca/http://climate.weather.gc. ca.

Fægri, K., Iversen, J., 1989. Textbook of Pollen Analysis, fourth ed. John Wiley \& Sons, Chichester, p. 328.

Forbes, B.C., Jefferies, R.L., 1999. Revegetation of disturbed arctic sites: constraints and applications. Biol. Conserv. 88, 15-24.

French, H.M., 1998. An appraisal of cryostratigraphy in north-west Arctic Canada. Permafr. Periglac. Process. 9, 297-312.

French, H.M., 2007. Thermokarst. In: French, H.M. (Ed.), The Periglacial Environment, third ed., pp. 186-215.

Fritz, M., Wetterich, S., Meyer, H., Schirrmeister, L., Lantuit, H., Pollard, W.H., 2011 Origin and characteristics of massive ground ice on Herschel Island (western Canadian Arctic) as revealed by stable water isotope and Hydrochemical signatures. Permafr. Periglac. Process. 22, 26-38.

Fritz, M., Wetterich, S., Schirrmeister, L., Meyer, H., Lantuit, H., Preusser, F. Pollard, W.H., 2012a. Eastern beringia and beyond: Late Wisconsinan and Holocene landscape dynamics along the Yukon Coastal Plain, Canada. Palaeogeogr. Palaeoclimatol. Palaeoecol. 319-320, 28-45.

Fritz, M., Herzschuh, U., Wetterich, S., Lantuit, H., De Pascale, G.P., Pollard, W.H., Schirrmeister, L., 2012b. Late glacial and Holocene sedimentation, vegetation, and climate history from easternmost Beringia (northern Yukon Territory, Canada). Quat. Res. 78, 549-560.

Fritz, M., Opel, T., Tanski, G., Herzschuh, U., Meyer, H., Eulenburg, A., Lantuit, H., 2015. Dissolved organic carbon (DOC) in Arctic ground ice. The Cryosphere 9, 737-752.

Grimm, E.C., 1987. CONISS: a FORTRAN 77 program for stratigraphically constrained cluster analysis by the method of incremental sum of squares. Comput. Geosci. $13,13-35$

Grimm, E.C., 2004. TGView 2.0.2 (Software). Illinois State Museum, Springfield.

Grosse, G., Jones, B., Arp, C., 2013. Thermokarst lakes, drainage, and drained basins. In: Shroder, J.F. (Ed.), Treatise on Geomorphology, vol. 8. Academic Press, San Diego, pp. 325-353.

Hammer, Ø., Harper, D., Ryan, P., 2001. Past: paleontological statistics software package for education and data analysis. Paleontol. Electrón. 4,1-9. URL. http:// palaeo-electronica.org/2001_1/past/issue1_01.html.

Harry, D.G., French, H.M., Pollard, W.H., 1985. Ice wedges and permafrost conditions near King Point, Beaufort Sea coast. Yukon Territ. Paper 85-1A, 111-116.

Harry, D.G., French, H.M., Pollard, W.H., 1988. Massive ground ice and ice-cored terrain near Sabine Point, Yukon Coastal Plain. Can. J. Earth Sci. 25, 1846-1856.

Horita, J., Ueda, A., Mizukami, K., Takatori, I., 1989. Automatic $\delta \mathrm{D}$ and $\delta^{18} \mathrm{O}$ analyses of multi-water samples using $\mathrm{H}_{2}$ and $\mathrm{CO}_{2}$-water equilibration methods with a common equilibration set-up. Int. J. Radiat. Appl. Instrum. Part A Appl. Radiat. Isotopes 40, 801-805.

Hugelius, G., Strauss, J., Zubrzycki, S., Harden, J.W., Schuur, E.A.G., Ping, C.L., Schirrmeister, L., Grosse, G., Michaelson, G.J., Koven, C.D., O'Donnell, J.A., Elberling, B., Mishra, U., Camill, P., Yu, Z., Palmtag, J., Kuhry, P., 2014. Estimated stocks of circumpolar permafrost carbon with quantified uncertainty ranges and identified data gaps. Biogeosciences 11, 6573-6593.

IAEA/WMO, 2015. Global Network of Isotopes in Precipitation. The GNIP Database. Accessible at: http://www.iaea.org/water.

Jankovská, V., Komárek, J., 2000. Indicative value of Pediastrum and other coccal green algae in palaeoecology. Folia Geobot. 35, 59-82.

Jones, B.M., Arp, C.D., 2015. Observing a catastrophic thermokarst lake drainage in northern Alaska. Permafr. Periglac. Process. 26, 119-128.

Jones, B.M., Grosse, G., Arp, C.D., Jones, M.C., Walter Anthony, K.M., Romanovsky, V.E., 2011. Modern thermokarst lake dynamics in the continuous permafrost zone, northern Seward Peninsula, Alaska. J. Geophys. Res. 116, G00M03.

Jones, M.C., Grosse, G., Jones, B.M., Walter Anthony, K., 2012. Peat accumulation in drained thermokarst lake basins in continuous, ice-rich permafrost, northern Seward Peninsula, Alaska. J. Geophys. Res. 117, G00M07.

Juggins, S., 2007. Software for Ecological and Paleoecological Data Analysis and Visualisation. C2. School of Geography. Politics \& Sociology. Newcastle University.

Kaufman, D.S., Ager, T.A., Anderson, N.J., Anderson, P.M., Andrews, J.T., Bartlein, P.J., Brubaker, L.B., Coats, L.L., Cwynar, L.C., Duvall, M.L., Dyke, A.S., Edwards, M.E., Eisner, W.R., Gajewski, K., Geirsdottir, A., Hu, F.S., Jennings, A.E., Kaplan, M.R., Kerwin, M.W., Lozhkin, A.V., MacDonald, G.M., Miller, G.H., Mock, C.J., Oswald, W.W., Otto-Bliesner, B.L., Porinchu, D.F., Ruhland, K., Smol, J.P., 
Steig, E.J., Wolfe, B.B., 2004. Holocene thermal maximum in the western Arctic $\left(0-180^{\circ}\right.$ W). Quat. Sci. Rev. 23, 529-560.

Kotler, E., Burn, C.R., 2000. Cryostratigraphy of the Klondike "muck" deposits, westcentral Yukon Territory. Can. J. Earth Sci. 37, 849-861.

Koven, C.D., Ringeval, B., Friedlingstein, P., Ciais, P., Cadule, P., Khvorostyanov, D., Krinner, G., Tarnocai, C., 2011. Permafrost carbon-climate feedbacks accelerate global warming. Proc. Natl. Acad. Sci. 108, 14769-14774.

Krammer, K., Lange-Bertalot, H., 1986. Bacillariophyceae. 1. Teil: naviculaceae. In: Ettl, H., Gerloff, J., Heynig, H., Mollenhauer, D. (Eds.), Süsswasserflora von Mitteleuropa, Band 2/1. Gustav Fischer Verlag, Stuttgart, New York, p. 876.

Krammer, K., Lange-Bertalot, H., 1988. Bacillariophyceae. 2. Teil: Bacillariaceae, Epithemiaceae, Surirellaceae. In: Ettl, H., Gerloff, J., Heynig, H., Mollenhauer, D. (Eds.), Süsswasserflora von Mitteleuropa, Band 2/2. VEB Gustav Fischer Verlag, Jena, p. 596.

Krammer, K., Lange-Bertalot, H., 1991. Bacillariophyceae. 3. Teil: Centrales, Fragilariaceae, Eunotiaceae. In: Ettl, H., Gerloff, J., Heynig, H., Mollenhauer, D. (Eds.) Süsswasserflora von Mitteleuropa, Band 2/3. Gustav Fischer Verlag, Stuttgart, Jena, p. 576.

Krantz, W.B., 1990. Self-organization manifest as patterned ground in recurrently frozen soils. Earth Sci. Rev. 29, 117-130.

Lachenbruch, A.H., 1962. Mechanics of thermal contraction cracks and ice-wedge polygons in permafrost. Geol. Soc. Am. Spec. Pap. 70, 1-66.

Lenz, J., Fritz, M., Schirrmeister, L., Lantuit, H., Wooller, M.J., Pollard, W.H., Wetterich, S., 2013. Periglacial landscape dynamics in the western Canadian Arctic: results from a thermokarst lake record on a push moraine (Herschel Island, Yukon Territory). Palaeogeogr Palaeoclimatol. Palaeoecol. 381-382, $15-25$.

Lenz, J., Grosse, G., Jones, B.M., Walter Anthony, K.M., Bobrov, A., Wulf, S., Wetterich, S., 2015. Mid-Wisconsin to Holocene permafrost and landscape dynamics based on a drained lake basin core from the northern Seward Peninsula, northwest Alaska. Permafr. Periglac. Process. http://dx.doi.org/ 10.1002/ppp.1848.

Mackay, J.R., 1959. Glacier ice-thrust features of the Yukon coast. Geogr. Bull. 13, $5-21$.

Mackay, J.R., 1972. The world of underground ice. Ann. Assoc. Am. Geogr. 62, 1-22.

Mackay, J.R., 1976. Ice-wedges as indicators of recent climatic change, western Arctic coast. Curr. Res. Geol. Surv. Can. Pap. 76-1A, 233-234.

Mackay, J.R., 1981. An Experiment in Lake Drainage, Richards Island, Northwest Territories: a Progress Report. Current Research, Part A. Geological Survey of Canada, Paper 81, pp. 63-68.

Mackay, J.R., 1983. Oxygen Isotope Variations in Permafrost, Tuktoyaktuk Peninsula Area, Northwest Territories. Current Research, Part B. Geological Survey of Canada, pp. 67-74.

Mackay, J.R., 1986. The first 7 years (1978-1985) of ice wedge growth, Illisarvik experimental drained lake site, western Arctic coast. Can. J. Earth Sci. 23, 1782-1795.

Mackay, J.R., 1988. Ice wedge growth in newly aggrading permafrost, western Arctic coast. In: Proceedings of the 5th International Conference on Permafrost, Trondheim, Norway. Tapir Publishers, Trondheim, pp. 2-5.

Mackay, J.R., 1992. . The frequency of ice-wedge cracking (1967-1987) at Garry Island, western Arctic coast, Canada. Can. J. Earth Sci. 29, 236-248.

Mackay, J.R., Burn, C.R., 2002. The first 20 years (1978-1979 to 1998-1999) of icewedge growth at the Illisarvik experimental drained lake site, western Arctic coast, Canada. Can. J. Earth Sci. 39, 95-111.

Meyer, H., Schönicke, L., Wand, U., Hubberten, H.W., Friedrichsen, H., 2000. Isotope studies of hydrogen and oxygen in ground ice - experiences with the equilibration technique. Isotopes Environ. Health Stud. 36, 133-149.

Meyer, H., Schirrmeister, L., Yoshikawa, K., Opel, T., Wetterich, S., Hubberten, H.-W., Brown, J., 2010. Permafrost evidence for severe winter cooling during the Younger Dryas in northern Alaska. Geophys. Res. Lett. 37, L03501.

Meyers, P.A., 1994. Preservation of elemental and isotopic source identification of sedimentary organic matter. Chem. Geol. 114, 289-302.

Michel, F.A., 1990. Isotopic composition of ice-wedge ice in northwestern Canada. In: Fifth Canadian Permafrost Conference. Collection Nordicana, Quebec City, pp. 5-9.

Murton, J.B., 2009. Stratigraphy and palaeoenvironments of Richards Island and the eastern Beaufort Continental Shelf during the last glacial-interglacial cycle. Permafr. Periglac. Process. 20, 107-125.

Murton, J.B., Bateman, M.D., 2007. Syngenetic sand veins and anti-syngenetic sand wedges, Tuktoyaktuk Coastlands, western Arctic Canada. Permafr. Periglac. Process. 18, 33-47.

Murton, J.B., French, H.M., 1994. Cryostructures in permafrost, Tuktoyaktuk Coastlands, western Arctic Canada. Can. J. Earth Sci. 31, 737-747.

Myers-Smith, I.H., Hik, D.S., Kennedy, C., Cooley, D., Johnstone, J.F., Kenney, A.J., Krebs, C.J., 2011. Expansion of canopy-forming willows over the twentieth century on Herschel Island, Yukon Territory, Canada. Ambio 40, 610-623.

Obu, J., Lantuit, H., Myers-Smith, I., Heim, B., Wolter, J., Fritz, M., 2015. Effect of terrain characteristics on soil organic carbon and total nitrogen stocks in soils of Herschel Island, western Canadian Arctic. Permafr. Periglac. Process. http:// dx.doi.org/10.1002/ppp.1881.

Ovenden, L., 1982. Vegetation history of a polygonal peatland, northern Yukon. Boreas 11, 209-224.

Ovenden, L., 1986. Vegetation colonizing the bed of a recently drained thermokarst lake (Illisarvik), Northwest Territories. Can. J. Bot. 64, 2688-2692.

Palagushkina, O.V., Nazarova, L.B., Wetterich, S., Schirrmeister, L., 2012. Diatoms of modern bottom sediments in Siberian Arctic. Contemp. Probl. Ecol. 5, 413-422.

Pienitz, R., Smol, J.P., Last, W.M., Leavitt, P.R., Cumming, B.F., 2000. Multi-proxy Holocene palaeoclimatic record from a saline lake in the Canadian Subarctic. The Holocene 10, 673-686.

Pollard, W., 1990. The nature and origin of ground ice in the Herschel Island area, Yukon Territory. In: Proceedings of the Fifth Canadian Permafrost Conference, Québec, pp. 23-30.

Rampton, V.N., 1982. Quaternary geology of the Yukon coastal plain. Geological Survey of Canada Bulletin 317, 49.

Rampton, V.N., 1988. Quaternary geology of the Tuktoyaktuk coastlands, Northwest Territories. Geological Survey of Canada Memoir 423, 98.

Reimer, P.J., Bard, E., Bayliss, A., Beck, J.W., Blackwell, P.G., Bronk Ramsey, C., Buck, C.E., Cheng, H., Edwards, R.L., Friedrich, M., Grootes, P.M., Guilderson, T.P., Haflidason, H., Hajdas, I., Hatté, C., Heaton, T.J., Hoffmann, D.L., Hughen, K.A. Kaiser, K.F., Kromer, B., Manning, S.W., Niu, M., Reimer, R.W., Richards, D.A. Scott, E.M., Southon, J.R., Staff, R.A., Turney, C.S.M., van der Plicht, J., Hogg, A., 2013. IntCal13 and Marine13 radiocarbon age calibration curves $0-50,000$ years cal BP. Radiocarbon 55, 1869-1887.

Rethemeyer, J., Fueloep, R.-H., Hoefle, S., Wacker, L., Heinze, S., Hajdas, I., Patt, U. Koenig, S., Stapper, B., Dewald, A., 2013. Status report on sample preparation facilities for ${ }^{14} \mathrm{C}$ analysis at the new Cologne AMS center. Nucl. Instrum. Methods Phys. Res. Sect. B 294, 168-172.

Reynolds, C.S., 2003. The development of perceptions of aquatic eutrophication and its control. Ecohydrol. Hydrobiol. 3, 149-163.

Ritchie, J.C., 1984. Past and Present Vegetation of the Far Northwest of Canada. University of Toronto Press, Toronto, p. 251.

Rowland, J., Jones, C., Altmann, G., Bryan, R., Crosby, B., Hinzman, L., Kane, D. Lawrence, D., Mancino, A., Marsh, P., 2010. Arctic landscapes in transition: responses to thawing permafrost. EOS Trans. Am. Geophys. Union 91, 229-230.

Schaefer, K., Lantuit, H., Romanovsky, V.E., Schuur, E.A., Witt, R., 2014. The impact of the permafrost carbon feedback on global climate. Environ. Res. Lett. 9, 085003.

Schirrmeister, L., Froese, D., Tumskoy, V., Wetterich, S., 2013. Yedoma: Late Pleistocene ice-rich syngenetic permafrost of Beringia. In: Elias, S.A. (Ed.), The Encyclopedia of Quaternary Science. Elsevier, Amsterdam, pp. 542-552.

Schirrmeister, L., Grosse, G., Wetterich, S., Overduin, P.P., Strauss, J., Schuur, E.A.G. Hubberten, H.-W., 2011. Fossil organic matter characteristics in permafrost deposits of the northeast Siberian Arctic. J. Geophys. Res. 116, G00M02.

Schuur, E.A.G., McGuire, A.D., Schadel, C., Grosse, G., Harden, J.W., Hayes, D.J. Hugelius, G., Koven, C.D., Kuhry, P., Lawrence, D.M., Natali, S.M., Olefeldt, D. Romanovsky, V.E., Schaefer, K., Turetsky, M.R., Treat, C.C., Vonk, J.E., 2015. Climate change and the permafrost carbon feedback. Nature 520, 171-179.

Smith, L.C., Sheng, Y., MacDonald, G.M., Hinzman, L.D., 2005. Disappearing Arctic lakes. Science 308, 1429.

Smol, J.P., Douglas, M.S., 2007. Crossing the final ecological threshold in high Arctic ponds. Proc. Natl. Acad. Sci. 104, 12395-12397.

Souchez, R., Jouzel, J., Lorrain, R., Sleewaegen, S., Stiévenard, M., Verbeke, V., 2000. A kinetic isotope effect during ice formation by water freezing. Geophys. Res. Lett. 27, 1923-1926.

Spetzman, L.A., 1959. Vegetation of the Arctic Slope of Alaska. Geological Survey professional paper No. 302B, pp. 19-59.

Stockmarr, J., 1971. Tablets with spores used in absolute pollen analysis. Pollen Spores 13, 615-621.

Ter Braak, C.J.F., Šmilauer, P., 2002. CANOCO reference manual and CanoDraw for Windows User's Guide: Software for Canonical Community Ordination (Version 4.5). Microcomputer Power (Ithaca NY, USA), p. 500.

Van Everdingen, R.O., 1998. Multi-language Glossary of Permafrost and Related Ground-ice Terms. National Snow and Ice Data Center/World Data Center for Glaciology, Boulder.

Van Geel, B., 2001. Non-pollen palynomorphs. In: Smol, J.P., Birks, H.J.B., Last, W.M (Eds.), Tracking Environmental Change Using Lake Sediments, Terrestrial, Algal, and Siliceous Indicators, vol. 3. Kluwer Academic Publishers, Dordrecht, The Netherlands, pp. 99-119.

Van Huissteden, J., Berrittella, C., Parmentier, F.J.W., Mi, Y., Maximov, T.C., Dolman, A.J., 2011. Methane emissions from permafrost thaw lakes limited by lake drainage. Nat. Clim. Change 1, 119-123.

Vardy, S.R., Warner, B.G., Aravena, R., 1997. Holocene climate effects on the development of a peatland on the Tuktoyaktuk Peninsula, Northwest Territories. Quat. Res. 47, 90-104.

Vardy, S.R., Warner, B.G., Aravena, R., 1998. Holocene climate and the development of a subarctic peatland near Inuvik, Northwest Territories, Canada. Clim. Change 40, 285-313.

Vardy, S.R., Warner, B.G., Asada, T., 2005. Holocene environmental change in two polygonal peatlands, south-central Nunavut, Canada. Boreas 34, 324-334.

Vardy, S.R., Warner, B.G., Turunen, J., Aravena, R., 2000. Carbon accumulation in permafrost peatlands in the Northwest Territories and Nunavut, Canada. The Holocene 10, 273-280.

Viau, A.E., Gajewski, K., Sawada, M.C., Bunbury, J., 2008. Low- and high-frequency climate variability in eastern Beringia during the past 25000 years. Can. J. Earth Sci. 45, 1435-1453.

Viau, A.E., Ladd, M., Gajewski, K., 2012. The climate of North America during the past 2000 years reconstructed from pollen data. Glob. Planet. Change 84-85, 75-83.

Wacker, L., Němec, M., Bourquin, J., 2010. A revolutionary graphitisation system: fully automated, compact and simple. Nucl. Instrum. Methods Phys. Res. Sect. B 268, 931-934. 
Walker, D.A., Raynolds, M.K., Daniëls, F.J., Einarsson, E., Elvebakk, A., Gould, W.A., Katenin, A.E., Kholod, S.S., Markon, C.J., Melnikov, E.S., 2005. The circumpolar Arctic vegetation map. J. Veg. Sci. 16, 267-282.

Walter Anthony, K.M., Zimov, S.A., Grosse, G., Jones, M.C., Anthony, P.M., Iii, F.S.C. Finlay, J.C., Mack, M.C., Davydov, S., Frenzel, P., Frolking, S., 2014. A shift of thermokarst lakes from carbon sources to sinks during the Holocene epoch. Nature 511, 452-456.

Wanner, H., Beer, J., Bütikofer, J., Crowley, T.J., Cubasch, U., Flückiger, J., Goosse, H., Grosjean, M., Joos, F. Kaplan, J.O., Küttel, M., Müller, S.A., Prentice, I.C. Solomina, O., Stocker, T.F., Tarasov, P., Wagner, M., Widmann, M., 2008. Mid- to Late Holocene climate change: an overview. Quat. Sci. Rev. 27, 1791-1828.

Wehr, J.D., Sheath, R.G., 2003. Freshwater Algae of North America. Academic Press, Burlington, p. 917.

Wetterich, S., Rudaya, N., Tumskoy, V., Andreev, A.A., Opel, T., Schirrmeister, L., Meyer, H., 2011. Last glacial maximum records in permafrost of the east Siberian
Arctic. Quat. Sci. Rev. 30, 3139-3151.

Wetterich, S., Tumskoy, V., Rudaya, N., Andreev, A.A., Opel, T., Meyer, $\mathrm{H}$, Schirrmeister, L., 2014. Ice Complex formation in arctic East Siberia during the MIS3 Interstadial. Quat. Sci. Rev. 84, 39-55.

Whitmore, J., Gajewski, K., Sawada, M., Williams, J.W., Shuman, B., Bartlein, P.J., Minckley, T., Viau, A.E., Webb III, T., Shafer, S., Anderson, P., Brubaker, L., 2005. Modern pollen data from North America and Greenland for multi-scale paleoenvironmental applications. Quat. Sci. Rev. 24, 1828-1848.

Wolter, J., Lantuit, H., Fritz, M., Macias-Fauria, M., Myers-Smith, I., Herzschuh, U. accepted. Vegetation composition and shrub extent on the Yukon coast, Canada, are strongly linked to ice-wedge polygon degradation. Polar Research.

Zibulski, R., Herzschuh, U., Pestryakova, L.A., Wolter, J., Müller, S., Schilling, N., Wetterich, S., Schirrmeister, L., Tian, F., 2013. River flooding as a driver of polygon dynamics: modern vegetation data and a millennial peat record from the Anabar River lowlands (Arctic Siberia). Biogeosciences 10, 5703-5728. 